\title{
Modulators of axonal growth and guidance at the brain midline with special reference to glial heparan sulfate proteoglycans
}

\author{
LENY A. CAVALCANTE ${ }^{1 *}$, JOSÉ GARCIA-ABREU ${ }^{2}$, VIVALDO MOURA NETO ${ }^{2}$, \\ LUIZ CLAUDIO SILVA ${ }^{3}$ and GILBERTO WEISSMÜLLER ${ }^{1}$ \\ ${ }^{1}$ Instituto de Biofísica Carlos Chagas Filho, CCS, \\ Universidade Federal do Rio de Janeiro (UFRJ), 21949-900 Rio de Janeiro, Brazil \\ ${ }^{2}$ Departamento de Anatomia, CCS, UFRJ \\ ${ }^{3}$ Departamento de Bioquímica and Hospital Universitário Clementino Fraga Filho, UFRJ \\ Manuscript received on October 7, 2002; accepted for publication on October 21, 2002; \\ contributed by Leny A. Cavalcante and Vivaldo Moura Neto
}

\begin{abstract}
Bilaterally symmetric organisms need to exchange information between the left and right sides of their bodies to integrate sensory input and to coordinate motor control. Thus, an important choice point for developing axons is the Central Nervous System (CNS) midline. Crossing of this choice point is influenced by highly conserved, soluble or membrane-bound molecules such as the L1 subfamily, laminin, netrins, slits, semaphorins, Eph-receptors and ephrins, etc. Furthermore, there is much circumstantial evidence for a role of proteoglycans (PGs) or their glycosaminoglycan (GAG) moieties on axonal growth and guidance, most of which was derived from simplified models. A model of intermediate complexity is that of cocultures of young neurons and astroglial carpets (confluent cultures) obtained from medial and lateral sectors of the embryonic rodent midbrain soon after formation of its commissures. Neurite production in these cocultures reveals that, irrespective of the previous location of neurons in the midbrain, medial astrocytes exerted an inhibitory or nonpermissive effect on neuritic growth that was correlated to a higher content of both heparan and chondroitin sulfates (HS and CS). Treatment with GAG lyases shows minor effects of CS and discloses a major inhibitory or non-permissive role for HS. The results are discussed in terms of available knowledge on the binding of HSPGs to interative proteins and underscore the importance of understanding glial polysaccharide arrays in addition to its protein complement for a better understanding of neuron-glial interactions.
\end{abstract}

Key words: astrocytes, axon growth, extracellular matrix, heparan sulfate, midline, midbrain.

\section{INTRODUCTION}

The establishment of the basic circuitry in complex systems such as the Central Nervous System (CNS) of vertebrates or higher invertebrates involves inter-

\footnotetext{
*All authors contributed equally to this work; names are in alphabetic order. This review is dedicated to Prof. Luiz Carlos $\mathrm{U}$. Junqueira, pioneer of the study of the extracellular matrix in Brazil, for his 82nd birthday.

Correspondence to: Dr. Leny A. Cavalcante E-mail: Leny@biof.ufrj.br
}

actions among growing axons and between growing processes and cell bodies of neuronal or nonneuronal cells at important choice points. As bilaterally symmetric organisms need to exchange information between the left and right sides of their bodies to integrate sensory input and to coordinate motor control, an important choice point is the CNS midline. At this site, growing axons decide whether to cross and project contralaterally or to remain on 
the same side of the body in patterns appropriate for a given species. After projecting contralaterally, it is also important that growing axons remain on the same side, i.e., avoid recrossing the midline at the same or at a different level of the rostro-caudal axis.

It has been known for several years that normal visually-mediated behavior depends on the crossing, at the optic chiasm, of axons from each eye to the opposite side of the brain in a proportion that is appropriate for each species. In goldfish, in which all optic axons cross normally, visuo-motor responses are severely affected if ipsilateral projections are surgically induced (Easter and Schmidt 1977). In humans, in which about half of the axons from each eye cross normally, an inborn malformation that prevents the development of the optic chiasm results in abnormal visual evoked potentials and faulty stabilization of visual images on the retina following movement of the visual environment (Apkarian et al. 1995).

Disturbances of motor behavior that, although less dramatic, are still inappropriate for the species are found in rats in which mutations in components of a receptor protein tyrosine kinase system induces partial recrossing of axons running from the cerebral cortex to the spinal cord - the corticospinal tract. Although relatively normal by many standards, such animals hop rather than walk, i.e., display a kangaroo-like motor pattern (Dottori et al. 1998, Kullander et al. 2001).

The corticospinal tract is also consistently malformed in the X-linked hydrocephalus (XLH) syndrome in which more than 80 different mutations have been identified in the cell adhesion molecule L1 (L1CAM) (Reviews: Brümmendorf et al. 1998, Kamiguchi et al. 1998). This syndrome, known by many names such as X-linked spastic paraplegia, $\mathrm{X}$ linked corpus callosum agenesis, etc has a parallel in L1 knock- out rodents by the occurrence of defects in the development of the corticospinal tract and cerebellar vermis, hydrocephalus and impaired learning. The loss of L1 function alters both axon guidance, particularly at the midline, and neural morphogenesis but probably by different mechanisms.
Axon growth encompasses elongation, interstitial branching and terminal branching (MendezOtero et al. 1985, Bhide and Frost 1991, Jhaveri et al. 1991) all of which are presumably influenced by extracellular signals. Molecular signals that direct the different phases of axon growth are primarily unknown; some of these signals may be intrinsically programmed in the neuron while others may be derived from the definite or from an intermediate target (Review: Kalil et al. 2000) as well as by "neighbor pioneer" axons (Henke-Fahle et al. 2001). In recent years, considerable effort has been made in what concerns the role of soluble or membrane-linked proteins on axonal/ neuritic growth at the midline (see section Some attractive and repulsive molecules at the midline). Investigation on these proteins has often benefited from complex models generated by genetic technology, that allow in vivo studies. However, results of numerous investigations of cell motility and axonal sprouting have suggested that glycolipids and other glycoconjugates serve important functions in cellsubstratum interactions and neurite extension ( $\mathrm{Re}$ views: Mendez-Otero and Santiago 2001, Santiago et al. 2001). Such studies have, in general, lagged behind those on similarly distributed proteins because of several technical difficulties.

The proteoglycans (PGs) and/or their glycidic moieties - glycosaminoglycans (GAGs) - involved in the axon guidance or growth have not been well characterized in vivo although it is expected that they are important for several reasons including the in vitro binding to chains of GAGs of proteins involved in these phenomena (e.g. Bennett et al. 1997). Recent studies using Drosophila mutants and transgenic mice indicate that, for instance, sulfation of heparan sulfate (HS) has important roles in developmental processes (Lin and Perrimon 1999, Lin et al. 1999). However, since HS interacts with various molecules that are essential for early morphogenesis, transgenic mice and Drosophila mutants that lack proper HS biosynthesis show multiple developmental defects (Bullock et al. 1998). Thus, it has been difficult to study the role of HS in late devel- 
opmental processes such as the formation of nerve connections.

We review here some recent studies on the effects of HS of axonal and glial proteoglycans on the specific events of neuritic growth and guidance at the CNS midline against the background of present knowledge on some of the best characterized attractive and repulsive protein molecules.

\section{THE MIDLINE OF THE CENTRAL NERVOUS SYSTEM}

Information about the role of the midline on the control of axon navigation comes from several sites but the best documented example in the vertebrate CNS is the spinal cord floor plate (Bovolenta and Dodd 1990, Bernhardt 1994), a set of primitive glial cells also recognized in the lower brainstem (Kingsbury 1930), where commissural axons traverse, turning at its contralateral border (Bovolenta and Dodd, 1990). Labeling of the commissural growth cones reveals changes in their morphology as they encounter distinct regions of the pathway, again suggesting some contact-mediated mechanism at the midline (Bernhardt 1994, Imondi and Kaprielian 2001). It is expected that at choice points there is differential expression of cell adhesion or extracellular matrix (ECM) molecules and it is known that the resident cells at the midline produce molecules that both direct, promote and/or inhibit axon growth across the midline (Review: Kaprielian et al. 2001).

The notochord and floor plate are not clearly defined in morphological terms at the ventral mesencephalon (ventral midbrain) and diencephalon midline in comparison with the rombencephalon (hindbrain) and spinal cord (Kingsbury 1930) but there is evidence that similar mechanisms control morphogenesis (Puelles 1995) as well as axon growth and guidance at these levels. In the diencephalon and midbrain midline, congregations of specialized glial cells (Barradas et al. 1989, Snow et al. 1990a, Marcus and Mason 1995, Marcus et al. 1995, Wu et al. 1995), transitory neurons (Sretavan et al. 1994, Marcus et al. 1995) and a growing number of molecules have been identified (Reviews: Mason and
Sretavan 1997, Kaprielian et al. 2001). For instance, the first retinal ganglion cell axons arriving at the embryonic mouse ventral diencephalon encounter an inverted V-shaped neuronal array defining the midline and posterior boundaries of the future optic chiasm. These neurons express L1, an immunoglobulin superfamily molecule known to promote retinal axon outgrowth, CD44, a cell surface molecule that inhibits embryonic retinal axon growth in vitro and a neuronal subpopulation expressing SSEA-1. Incoming retinal axons do not penetrate this L1/CD44/SSEA-1 neuron array, but turn to establish the characteristic X-shaped optic chiasm along the anterior border of this array. It has been hypothesized that L1/CD44 neurons may serve as an anatomical template for retinal axon pathways at the embryonic mouse ventral diencephalon.

The roof plate localized at the dorsal midline of the spinal cord, midbrain and diencephalon has been described as a transient barrier for axonal elongation (Jhaveri 1993). The resident radial glial cells of the roof plate suffer changes in their arrangement and density and express selectively certain ECM molecules, such as keratan and chondroitin sulfates. The presence of these GAGs plus the behavior of dorsal root ganglion axons growing on a substrate containing keratan and chondroitin sulfate has led to the suggestion that glial cells at the roof plate may be responsible for preventing crossing of neurites through the dorsal midline (Snow et al. 1990a). However, it is not clear whether the roof plate has similar properties along its entire rostro-caudal axis since the diencephalic roof plate (subcommissural organ), together with the rombencephalic floor plate are the source of secretory compounds of related nature that are not produced in any other level of the roof or floor midline (Yulis et al. 1998).

It has been known for some time that nonneuronal cells in the dorsal brain stem midline differ from their lateral neighbors in their ability to take up exogenous label borne by afferent axons (Barradas et al. 1989, Kageyama and Robertson 1993) as well as in glycogen deposition, binding of antibodies against $\mathrm{S}-100$ protein, $\mathrm{RC} 1$ and $\mathrm{R} 2 \mathrm{D} 5$ anti- 
gens, cytoskeletal components and annexins (Van Hartesveldt et al. 1986, Barradas et al. 1989, Snow et al. 1990a, Mori et al. 1990, McCabe and Cole 1992, Hamre et al. 1996, Wu et al. 1995). It is interesting to notice that both the floor plate and the roof plate at both cord and midbrain (median ventricular formation) levels, together with the lamina terminalis, are part of the discrete embryonic sites containing cells which have exited the cell cycle very early during embryogenesis (Raedler et al. 1981, Kahane and Kalcheim 1998). It has been hypothesized that this early withdrawal from the cell cycle contributes to modeling the morphology of the SNC (Kahane and Kalcheim 1998).

\section{SOME ATTRACTIVE AND REPULSIVE MOLECULES AT THE MIDLINE}

Studies of midline crossing in the invertebrate ventral cord and in the vertebrate spinal cord have provided a wealth of information applicable to the interpretation of the molecular mechanisms involved in the elongation mode. This information has been often reviewed in excellent texts (Cf., for instance, Tessier-Lavigne and Goodman 1996, Fitch and Silver 1997, Dow and Wang 1998, Brose and TessierLavigne 2000, Kaprielian et al.2001, Ba-Charvet and Chédotal 2002) and only a few comments, with potential relevance to the function of proteoglycans, will be mentioned here. Families of guidance molecules that are remarkably conserved in structure and function in vertebrates and invertebrates are the L1 subfamily (members of the immunoglobulin superfamily), laminin, netrins, semaphorin and Eph (erythropoietin-producing hepatocellular) receptors- ephrin (Eph-receptor-interacting proteins) families.

\section{L1 Subfamily}

The L1 proteins subfamily comprises four vertebrate members - L1, neurofascin, NrCAM (neuronglia cell adhesion molecule related cell adhesion molecule), and CHL1 (close homologue of L1) - and two invertebrate members - neuroglian and tractin. They are characterized by six Ig-like domains, at least four fibronectin type III repeats, and highly conserved cytoplasmic domains. L1 is predominantly expressed in the developing CNS and peripheral nervous system. Homophilic L1-L1 binding between adjacent membranes of neurons is probably the most common mode of action, and the second Iglike domain in the L1 extracellular domain (L1ED) is sufficient to mediate homophilic adhesion. However, a variety of heterophilic binding partners for $\mathrm{L} 1$ have also been identified such as $\beta 1$ and $\beta 3$ integrins whose binding can promote neurite growth from dorsal root ganglion neurons. It is also clear that L1 functions as a signal-transducing receptor and can influence growth cone and cell migration behavior in response to ligand binding (Brümmendorf et al. 1998).

A detailed examination of the corticospinal tract in L1 deficient mice revealed that this protein is important for the guidance of corticospinal axons across the pyramidal decussation at the hindbrain/ spinal cord boundary. In one type of Ll-deficient mice, corticospinal axons appear to extend normally to the caudal medulla, at the decussation; however, only very few axons grow to the contralateral dorsal column (Cohen et al. 1998), as in the normal projection. Instead, many axons grow ventrally and enter the contralateral pyramid although this error may be corrected later in development. In another L1 knock-out mouse, a decreased size of the corticospinal tract at the level of the caudal medulla was observed (Dahme et al. 1997), a finding that may be related to a role of $\mathrm{L} 1$ in neurite fasciculation.

It is unclear whether L1 is essential for other commissural pathways (e.g. optic chiasm and the spinal cord ventral commissure). Early work in the rat reported that commissural axons start to express L1 only after crossing the midline (Dodd et al. 1988) whereas in the chick both ipsi- and contralateral portions of commissural axons express a closely related CAM protein (Shiga et al. 1990). However, recent reexamination of this presumptive species variation indicated that L1 was expressed on rat commissural axons in a pattern similar to that observed in the chick (Tran and Phelps 2000). It is interesting to 
notice that many axons of the late-developing dorsal spinal commissure also express L1 (Orlino et al. 2000). Another remarkable fact is that both axons that course through the ventral midline areas and specialized glial formations that occur at this site, including the floor plate in the spinal cord, the hindbrain and midbrain, the optic chiasm, and the median eminence in the forebrain are immunoreactive for Nr-CAM, a member of the L1 subfamily (Lustig et al. 2001).

\section{LAMININS}

The laminins are a 15 member family of large cruciform glycoproteins (Timpl et al. 1979) containing five different $\alpha$ chains $(\alpha 1-\alpha 5)$ of 200-400 kDa which combine with $\beta(220 \mathrm{kDa})$ and $\gamma(210 \mathrm{kDa})$ chains into disulfide-bonded heterotrimers. The Cterminal globular domains of the $\alpha$ chain are critical for driving laminin polymerization and heparin binding (Yurchenco et al. 1985, 1990). Several other ECM molecules may bind laminin through these globular domains, such as perlecan and $\alpha$ dystroglycan (Talts et al. 1999). In the central nervous system, laminins are produced by astroglia (Liesi and Silver 1988) and neurons (Zhou 1990) and their potent axon growth and guidance capacities have been demonstrated repeatedly in tissue culture assays (Luckenbill-Edds 1997). Accordingly, laminin immunoreactivity has been described along acellular spaces where future fiber bundles will form, increasing in expression during the stage when many nerve fibers are navigating to their targets (Zhou 1990). Nevertheless, laminin together with putative inhibitory molecules such as chondroitin sulfate and tenascin-C, forms "tunnels" that constrain anterior commissure axons as they cross the midline (Pires-Neto et al. 1998).

It is possible that differences in tertiary or quaternary structure of laminin should be of higher biological significance than its mere presence. In an in vitro model of glia-neurite interactions at the midbrain midline, Garcia-Abreu and coworkers (1995a, b) showed that astrocytes derived from medial midbrain sectors presented a punctate distribu- tion of laminin and poor neurite growth-supporting whereas astrocytes originating from lateral midbrain sectors exhibited a fibrillary distribution of laminin and an exemplary propensity to support neurite growth. To our knowledge, there are no other examples on functionally-related patterns of lamininimmunoreactive structures at the midline. It should be noted, in passing, that punctate and fibrillary patterns of laminin immunoreactivity have also been observed in reactive astrocytes that express GFAP (laminin punctate pattern) and GFAP-null mutants (laminin fibrillary pattern) in correlation with their permissive and non-permissive nature, respectively (Lefrançois et al. 1997, Tardy 2002).

\section{NETRINS}

Netrins, proteins of about 600 aminoacids, related to but smaller than laminins, and their receptors, termed DCC (product of the gene Deleted in Colorectal Carcinoma), are bifunctional guidance cues (Fazeli et al. 1997). Netrin 1 is produced by floor plate cells at the spinal chord midline and is required as an attractant of commissural axons from the dorsal spinal cord and as a repellent of axons that migrate away from the midline (Colamarino and Tesser-Lavigne 1995, Varela-Echavarria et al. 1997). Both attractive and repulsive responses of axonal growth cones to Netrin-1 seem to be mediated, at least partially, by DCC and require the presence of extracellular calcium (Ming et al. 1997). Both laminin-1 from ECM and low levels of cyclic AMP in growth cones convert netrin-mediated attraction into repulsion (Hopker et al. 1999). Netrins and their receptor DCC bind heparin, indicating that GAGs may modulate their biological actions in a similar fashion as described for several other ligandreceptor systems (Kappler et al. 2000).

\section{SLIT}

Negative guidance molecules are important for guiding the growth of axons and ultimately for determining the wiring pattern in the developing nervous system. It is interesting to notice that studies of the arborization mode of axonal development led to the 
discovery of a repulsive guidance system that prevents inappropriate axons from crossing or recrossing the CNS midline (Brose and Tessier-Lavigne 2000). This repulsive system, identified from genetic studies in Drosophila, is mediated by secreted ligands - slit - and their Roundabout (Robo) receptors. Three distinct slit genes (Slit1, Slit2 and Slit3) and three distinct robo genes (robol, robo2 and rig1) have been cloned in mammals. The mammalian homologues of slit are ligands of the heparan sulfate proteoglycan (HSPG) glypican-1 (Liang et al. 1999, Ronca et al. 2001).

In collagen gel cocultures, slit1 and slit 2 can repel and collapse olfactory axons in explant cultures and this repulsion involves heparan sulfate $(\mathrm{Hu}$ 2001). In addition to a repulsive effect, there is a branching effect associated with slits (Ba-Charvet and Chédotal 2002), as slit2 stimulates the formation of axon collateral branches by NGF-responsive neurons of the dorsal root ganglia (DRG). Interestingly, slit is found at both the floor and the roof plate (Kaprielian et al. 2001), thus, in positions to discourage axons to cross the dorsal midline and to prevent recrossing of the ventral midline.

Slit 2 is expressed in the preoptic area while slit1 is expressed at the optic chiasm (Erskine et al. 2000) and the latter may be partially responsible for the growth-reducing effect of chiasmatic cells (Wang et al. 1995). Disruption of both Slit1 and Slit 2 genes in mice causes many defects such as the development of a large additional, rostral chiasm (loss of slit 2), the appearance of retino-retinal projections and ectopical extension of axons dorsally and laterally to the chiasm but maintenance of both an ipsilateral and a contralateral projection (Plump et al. 2002). Thus, it appears that slit proteins have no true guidance function in contrast, for instance, with slit at the midline of the Drosophila ventral cord.

The loss of slit expression may result in complex consequences in the trajectory of forebrain tracts, since slit 2 appears to be expressed by radial glia and diffuse to their processes in the ventral forebrain, and few axons cross the midline through the corpus callosum. That suggests that callosal neurons are sensitive to slit proteins prior to midline crossing (Bagri et al. 2002), thus differing from contralaterally-projecting axons in the spinal cord (Zou et al. 2000). In late embryos of mice carrying loss-of-function alleles of both Slit1 and Slit2, most cortical fibers that enter the internal capsule are directed to a ventral position toward the midline, some of which cross it, turn around and return toward the midline while other axons cross in a large ectopic commissure (Bagri et al. 2002).

Axons that encounter a gradient of inhibitory proteins tend to tight axon fasciculation and avoid aberrant growth into inappropriate sites. In addition to slit, families of molecules that cause growth cone collapse have been identified, including semaphorins and ephrins.

\section{Semaphorins}

The semaphorins form a large family of signaling molecules that have been known for some years to repel or, less often, to attract specific axons in culture and/or to affect axon guidance in vivo (Reviews: Raper 2000, Tamagnone and Comoglio 2000). Semaphorins can be distinguished by their biochemical structures as being secreted, membrane glycosylphosphatidyl-inositol (GPI)-anchored or transmembrane molecules. Semaphorins function through receptors consisting of plexins (transmembrane semaphorins) or neuropilin-plexin complexes (soluble semaphorins and neuropilin-1 and/or neuropilin 2).

The clearest demonstration that ipsilateral and contralateral axons from a given pathway may respond differentially to a diffusible semaphorin has been obtained for tecto-bulbar (ipsilateral) and tectospinal (contralateral) axons of the chick brain in their response to semaphorin 3A (Henke-Fahle et al. 2001). The conclusion, obtained from cocultures of explants from the tectum and the (diencephalic) site of origin of axons of the medial longitudinal fascicle, is that this fascicle is the source of semaphorin $3 \mathrm{~A}$ that repels the neuropilin-1-expressing tecto-bulbar fibers. Molecules of the slit family appear not to be 
involved in the discrimination between (chick) midbrain axons destined to cross the midline or to remain ipsilateral at very early stages such as the time of development of tecto-bulbar and tecto-spinal fibers. According to Henke-Fahle and coworkers (2001) outgrowth from tectal explants is unaffected by the floor plate and/or slit 2, raising the possibility that there are species-specific differences with respect to the relative contribution of slit and semaphorins to axon guidance at the midline. Indeed, previous work in the rat had suggested that the floor plate at all axial levels displayed both chemoattractive and chemorepellent activities (Tamada et al. 1995). Interestingly, Zou et al. (2000) have shown that Slit-2 and two semaphorin proteins (Sema 3B and Sema 3F) contribute to repelling commissural axons that have crossed the midline floor plate at the spinal cord, directing them away from the ventral gray matter and into the surrounding fiber tracts.

As mentioned previously, defects of the corticospinal tract in humans have often been attributed to mutations in the gene encoding L1 CAM, a phenotype that is reproduced in L1-deficient mice. It is interesting to notice that Sema3A secreted from ventral spinal cord explants repels cortical axons from wild-type but not from L1-deficient mice. L1 and neuropilin-1 (NP-1) form a stable complex and their extracellular domains can directly associate (Castellani et al. 2000).

With regard to a role for semaphorins mediated by the receptor neuropilin 2 , several central tracts including the anterior commissure presented marked defects in neuropilin-2 loss-of-function mutants, together with several cranial nerves, the initial central projections of spinal sensory axons, etc (Chen et al. 2000). To our knowledge, there is no evidence for a role of anchored- or transmembrane semaphorins in control of axon growth and guidance at the midline.

\section{EPH RECEPTORS AND EPHRINS}

One group of putative guidance molecules that is amongst the most intensely studied at present is that formed by the Eph family of receptor tyrosine kinases and their ligands (ephrins), more extensively considered in all vertebrate classes (Orioli and Klein 1997, Holder and Klein 1999) but also identified in C. elegans (George et al. 1998), Drosophila (Scully et al. 1999) and even in a sponge (Suga et al. 1999). The Eph receptors-ephrins group contains at least 14 different receptors and 8 ligands that are divided into two subclasses: 1. The EphA receptors that interact preferentially with GPI-anchored, A-class ephrin ligands and EphB that interact preferentially with transmembrane B-class ephrin ligands. Within each subclass, receptors bind to more than one ligand and ligands can activate more than one receptor, with the Eph A4 receptor being able to bind significantly to some of the transmembrane ligands, in addition to all of the GPI-linked ligands. Furthermore, recent evidence suggests that both EphA receptors and GPI-anchored ephrin-As can function as receptors and play important roles in development of the retinotectal and vomeronasal projections. Data from neuronal and non-neuronal cell lines indicate that EphAs and ephrin-As activate the same signaling pathways but in opposite directions (Knöll and Drescher 2002).

One of the first evidence implicating Eph receptors - EphB2 - in axon guidance in the embryo came from targeted mutation studies in the mouse (Henkemeyer et al. 1996). An embryo homozygous for loss of EphB2 function lacked part of the anterior commissure and the loss of commissural axons was even more dramatic in mice null for both EphB2 and EphB3 (Orioli et al. 1996). However, as the neurons of origin of the anterior commissure do not express EphB2, the authors suggested that the phenotype might reflect loss of signaling through the ligand to which it normally binds.

Mice with a null mutation of the Eph A4 gene also presented deficiencies in the anterior commissure but their most noticeable trait was an abnormal locomotion pattern, described as a kangaroolike gait that resulted from an aberrant cortico-spinal tract (Dottori et al. 1998). This tract commands voluntary movement by ultimately connecting the motor cerebral cortex with interneurons and spinal cord motoneurons in the contralateral side (Kuypers 
1981). In the normal tract, axons from each side of the cortex proceed to the caudal medulla where most of them cross or decussate the midline to the contralateral side, descending via the dorsal funiculus of the spinal cord in rodents and other non-primate mammals. More recently, it has been demonstrated that ephrin B3 knock-out mice presented the same abnormal locomotion pattern and recrossing of the cortico-spinal tract at the cord midline as Eph A4 knock-out mice (Kullander et al. 2001). Thus, binding of ephrin B3 to Eph A4 receptors provides the repulsive signal that prevents axons from recrossing the midline.

Eph-related receptors of the A subclass and their ligands appear also to be implicated in the inhibition of retinal neurite growth, particularly of uncrossed neurites, by hypothalamic neurons and glia at the optic chiasm (Marcus et al. 2000, Cf. also Wang et al. 1995). Blocking of Eph A subclass interactions reduces both the inhibition and the differential response or retinal neurites in hypothalamic cells aggregates, with ephrin A1 binding suggesting a preferential repulsive response of a chiasmatic radial glial palisade (Marcus and Mason 1995, Marcus et al. 1995) and EphA2 and EphA5 binding suggesting a selective response of the chiasmatic CD44/ SSEA neurons (Sretavan et al. 1994, Marcus et al. 1995). Interestingly, ephrin B2 labeling concentrates in the region overlapping the radial glia midline palisade (Marcus et al. 2000). It has, in fact, been postulated that the presence or absence of ipsilateral projections from the eye to the brain in a given species is related to the Eph receptor- transmembrane ephrin system (Nakagawa et al. 2000). Ephrin-B is found in the chiasm of mammals, which have ipsilateral projections, but not in the chiasm of fish and birds, which do not have such projections.

Imondi and coworkers (2000) demonstrated that all three Eph family transmembrane ligands, ephrin-B1, ephrin-B2, and ephrin-B3, are expressed in the floor plate region of the spinal cord with ephrin-B3 mRNA being highly restricted to the midline. Furthermore, a receptor for these ligands is absent on commissural axons en route to the floor plate, but is highly expressed on those axonal segments that have crossed the ventral midline. Moreover, all three transmembrane ligands collapsed commissural growth cones, in vitro, thus, reinforcing the notion that ephrin-B class ligands and EphB1 constitute a contact-mediated, repulsive midline guidance system (Imondi et al. 2000, Kaprielian et al. 2001).

The momentous issue of involvement of the Eph receptor-ephrins system in the establishment of the retinotopic map in the midbrain tectum has perhaps demoted the role of this system in the crossing of the midbrain midline. However, targeted disruption of the EphA8 receptor results in an abnormality in the projection of axons leaving the superior colliculus of the midbrain which contains normally a subset of neurons expressing EphA8. In mice with a disrupted EphA8 gene, most of the projections from the superior colliculus are normal, but there is a reduction in axons projecting to the contralateral inferior colliculus. Instead, a new projection appears in the ipsilateral spinal cord, implying an effect on axon guidance (Park et al. 1997). Candidate ligands for EphA8 that might be involved in this guidance include ephrin-A2 and ephrin-A5, particularly ephrin-A5, postulated as providing a posterior barrier that could normally prevent axons with EphA8 from growing caudad and, thus, divert them to the contralateral inferior colliculus (Park et al. 1997). At the present time, it is known that both ephrin-A1 and ephrin-A4 ligands bind efficiently to the EphA8 receptor expressed in fibroblasts (Choi et al. 1999) but it is not known whether this fact has any functional relevance for axon growth and guidance at the midbrain midline.

\section{Receptor Tyrosine Phosphatases}

Phosphotyrosine signaling is finely regulated by the action of multiple protein tyrosine kinases and protein tyrosine phosphatases, many of which are receptor-like molecules (receptor-like protein tyrosine phosphatases, RPTPs) and most of these are highly expressed in developing nervous systems (Review: Stoker 2001). These receptor-like RPTPs 
are composed of an extracellular domain, a single transmembrane domain, and a cytoplasmic portion that contains one or two tyrosine phosphatase domains. RPTPs often reside in axonal shafts as well as in the membranes of growth cone lamellipodia and filopodia strongly suggesting roles in nerve development.

$\operatorname{RPTP} \beta$ (also known as $\mathrm{PTP} \xi$ ) and $\mathrm{RPTP} \gamma$ are two members of a subfamily of RPTPs that contain a region in their extracellular domains that has sequence homology to the enzyme carbonic anhydrase (CAH) (Barnea et al. 1994, Stoker 2001). Three different isoforms of RPTP $\beta$ are expressed as a result of alternative mRNA splicing: a short and a long transmembrane forms and a secreted form composed of only the extracellular domain of $\operatorname{RPTP} \beta$, also known as 3F8 proteoglycan or phosphacan. Both transmembrane RPTP $\beta$ s and the phosphacan isoform are predominantly expressed as chondroitin sulfate proteoglycans (Maurel et al. 1994).

Phosphacan binds to the cell adhesion molecules, N-CAM, L1, and TAG-1 (Milev et al. 1994, 1996). Phosphacan binding to TAG-1 depends largely upon the presence of its chondroitin sulfate chains since soluble chondroitin sulfate is an effective inhibitor of phosphacan-TAG-1 interactions (Milev et al. 1996).

The three isoforms of RPTP $\beta$ are expressed throughout the developing and adult nervous system. Interestingly, RPTP $\beta$ / phosphacan is also found in certain locations during development such as the roof plate (Meyer-Puttlitz et al. 1996), a structure that axons avoid for an extended developmental period (Smith 1983, Orlino et al. 2000), in apparent contradiction to an induction of neurite outgrowth through contactin and Nr-CAM. Sakurai and coworkers (1997) remarked that such a discrepancy was due to the roof plate of the spinal cord being deficient in adhesion molecules in general while the fiber tracts have a rich assortment of CAMs (see also Faissner et al. 1994, Garwood et al.1999). Therefore, it is likely that RPTP $\beta$ / phosphacan differentially affects neurite growth depending on the rela- tive abundance of the different forms of the molecule. Responses may also vary depending on the receptors available in particular neurons as well as on extracellular binding proteins such as tenascin. At the present time, the function of $\operatorname{RPTP} \beta$ / phosphacan in brain development is rather enigmatic, as there seems to be no obvious brain abnormalities in mice deficient in the three isoforms of $\operatorname{RPTP} \beta$ (Harroch et al. 2000).

In Drosophila, loss of function of the gene DPTP69D causes breaks in longitudinal midline fascicles as well as growth of longitudinal axons across the midline. This phenotype is greatly enhanced when both DPTP69D and DPTP10D functions are lost and is massively enhanced if the four genes DLAR, DPTP69D, DPTP10D and DPTP99A are all mutated. Thus, it has been suggested that Drosophila RPTPs are essential for transmission of the repulsive signal from Slit (Sun et al. 2000). Loss of function in Drosophila RPTP genes causes defasciculation and aberrant axon branching into incorrect territories at the midline whereas loss of function in motor axons results in tighter fasciculation and failure to branch into correct, new territories. That suggests that the cellular role of a given RPTP may be dependent on its specific cellular context.

RPTP $\delta$, a phosphatase that interacts homophilically causes attractive turning of neurites from forebrain neurons in culture, that is independent of cyclic nucleotide influences. RPTP $\delta$ mRNA has been detected in the rat floor plate while $\operatorname{RPTP} \psi$ mRNA was identified first in the roof and then in the lateral edges of the floor plate (Sommer et al. 1997). It remains to be determined which roles these receptor tyrosine phosphatases have in axon growth and guidance at the midline.

\section{PROTEOGLYCANS AND GLYCOSAMINOGLYCANS}

A very large number of different proteoglycans is expressed in the CNS and a variety of these molecules have been implicated in the regulation of neurite outgrowth during development and regeneration (Reviews: Bandtlow and Zimmermann 2000, Hartmann 
and Maurer 2001). Proteoglycans consist of core proteins and covalently attached GAGs side chains; GAGs are linear polysaccharides of 20-200 sugars in length, built by sequential addition of identical disaccharide units onto a characteristic linkage region (Lander 1993). Three types of disaccharide may be used, giving rise to three families of GAGs: the heparin/ heparan family, the chondroitin/ dermatan family, and the keratan family. The sugars of most GAGs are further chemically modified, e.g., by $O$ - or $N$-sulfation, and GAGs are subsequently referred to as chondroitin sulfate (CS), dermatan sulfate (DS), keratan sulfate (KS), heparin, and heparan sulfate (HS) (Lander 1993, Lander et al. 1999). However, core proteins are not just scaffolds for GAGS; they contain domains that have specific biological activities (Iozzo 1998).

Most PGs that are constituents of ECM in the mature brain are hyalectans (hyaluronic and lectin binding PGs) or lecticans and carry mainly CS side chains (CSPGs). There are also some sequence similarities in the genes encoding hyalectans and CD44, a transmembrane glycoprotein that is the main cell surface receptor for hyaluronic acid (HA) and carries a variable number of CS side chains. CD44 has 10 or more different isoforms, with variable abilities to bind HA or heparan sulfate (Piepkorn et al. 1999). Other secreted PGs are the keratancontaining and keratan-devoid variants of the soluble form of RPTP $\delta$ phosphatase or phosphacan and its mouse homologue DSD1 (Faissner et al. 1994, Garwood et al. 1999). In the developing mammalian brain, aggrecan family proteoglycans, phosphacan/RPTP $\beta / \xi$, and neuroglycan C (NGC) are the major classes of chondroitin sulfate proteoglycans (Oohira et al. 2000).

HS side chains are covalently attached to a protein core in HS proteoglycans (HSPGs) which may belong to one of three broad classes: (1) those associated with the cell membrane and which may have a GPI anchor such as the glypicans; (2) the transmembrane forms such as the syndecans; (3) those HSPGs that are secreted by cells and located in the ECM such as perlecan (Iozzo 1998, Sanderson and
Lander 1999). Heparan sulfate chains can vary in length, epimerization of glucuronic acid to iduronic acid, overall sulfation of the chains, and position of sulfation of the monosaccharides.

\section{Non-Neuronal CS/KS/DSPGs Modulation of} Neurite Growth at the Midline and Other SiTES

The notion that proteoglycans or, more precisely, that CSPGs may contribute to a barrier function at the SNC midline can be dated to the seminal work of Snow et al. (1990a), detailing the developmental cytological changes in the cord roof plate in rat embryos, a site avoided by dorsal root ganglion axons (Smith 1983), and reporting on the presence of a keratan sulfate-like immunoreactivity in the roof plate. The same epitope disappeared from the dorsal midline of the spinal cord at the time of formation of the dorsal commissure (Smith 1983, Cf. also Orlino et al. 2000) and was detected in the dorsal midline of the optic tectum in neonate hamsters (Snow et al. 1990a) during the growth of retinal axons (Frost et al. 1979), a population that must be prevented from crossing the midbrain midline. In a subsequent analysis employing nitrocellulose-coated culture dishes as a substratum to attach laminin (or N-CAM) and proteoglycans of interest, the behavior of the main target population - dorsal root ganglion (DRG) neurons - in explant cultures was evaluated and showed a general inhibitory effect of KS/CS-PGs, DS-PG and, in much smaller measure, of a chondrosarcoma tumor cell CS-PG, devoid of KS and predominantly 4-sulfated (Snow et al. 1990b). It is interesting to notice that Dou and Levine (1995) showed subsequently that chondroitin 4-sulfate (CS-4), CS-6 and KS inhibit neurite outgrowth from both cerebellar and DRG neurons on laminin-coated surfaces whereas DS and HS had no effect on these neurons under similar conditions.

Additional work by Snow and coworkers (1996) showed that soluble CSPGs (versican-like, aggrecan-like, etc) at different concentrations inhibited neurite outgrowth from DRG neurons and decreased the rate of neurite elongation on a fibronectin 
substratum but had little or no effect on neurite initiation or outgrowth on a laminin substratum. However, not all neurite inhibitory effects of CSPGs should be attributed to CS. For instance, $\mathrm{CS}$ chains of CSPG-enriched fractions such as brevican and versican V2-enriched fractions from bovine myelin contribute only to a minor extent to the inhibition of neurite growth of cerebellar neurons and the major activity seems to reside in the protein cores (Niederöst et al. 1999).

Unilateral application of a mixture of soluble CS- 4 and CS- 6 to the exposed brain of stage 28 Xenopus embryos caused navigation errors of a subpopulation expressing NOC-2, a novel glycoform of the neural cell adhesion molecule, of forebrain axons within the tract of the postoptic commissure (TPOC - Anderson et al. 1998). Interestingly, immunoreactive native proteoglycans containing CS-4 or CS6 were widely expressed in the untreated Xenopus brain and neither delineated channels, pathways, or specific choice points. In spite of that, exogenous CS caused misrouting in ways that differed from those of NOC-2 mutants, interfering with crossing of the ventral midline in the preexistent ventral commissure to join the contralateral TPOC. Navigational errors were either persistent longitudinal growth into the ventral longitudinal tract or, less often, premature exit from the ipsilateral TPOC and dorsad extension into the diencephalon or midbrain. It was not verified whether navigational errors were restricted to the subpopulation expressing NOC-2, but it was clear that axon elongation was neither inhibited nor promoted. For this and other reasons, the authors proposed that exogenous chondroitin sulfates affected axon guidance by competing off a bound molecule, possibly netrin 1 , from native CSPGs. However, this hypothesis was not tested further (Anderson et al. 2000).

It should also be mentioned, in passing, that axonal response to CS-4 and CS-6 might differ in some commissural systems (Fernaud-Espinosa et al. 1996). CS-4 was localized within the pathway of growing, neurofilament-reactive axons of the rat anterior commissure, while the course of tightly fas- ciculated axons was totally devoid of CS-6 which was, however, present in the surrounding regions (Cf. also Pires-Neto et al. 1998).

An analysis of axon routing at the embryonic mouse optic chiasm after enzymatic removal of chondroitin sulfate from living slices showed several age-related errors. At an early stage there was crossing of the midline at aberrant positions including formation of a retino-retinal pathway, at an intermediate stage there was abolition of the transient ipsilateral projection from the central retina, and at a late stage there was marked reduction of the ipsilateral projection from the temporal retina (Chung et al. 2000). At any stage, there were increases in the area and complexity of growth cones both in premidline and postmidline sites. Interestingly, although retinal fibers express L1, such pathfinding defects had not been apparent in L1 mutant mice (Cohen et al. 1998). It remains to be determined how the CS moieties of PGs modulate axon routing at the optic chiasm.

In view of the experimental evidence for a midline barrier to retinal axons at the midbrain tectum in mammals (Barradas et al. 1989, Jhaveri 1993), a simplified system was developed by Garcia-Abreu and coworkers $(1995 \mathrm{a}, \mathrm{b})$ to test the behavior of embryonic midbrain neurons on astroglial substrates derived from medial and lateral sectors of the embryonic (E14) midbrain (Fig. 1). Furthermore, correlations were sought between the outgrowth-inhibitory (medial astrocytes) and outgrowth-promoter (lateral astrocytes) of these relatively immature glial cells to their content of sulfated glycosaminoglycans (Table I - Cf. also Garcia-Abreu et al. 1996) and revealed that midbrain medial astrocytes synthesize about 1.65 times more [extracellular + pericellular] CS per unit time than lateral astrocytes. A similar ratio (medial/ lateral) was also found for the entire complement of sulfated GAGs in comparisons of the entire tectal midbrain tissue of neonate hamsters (Hoffman-Kim et al. 1998). These authors also demonstrated that PG cores are expressed at similar relative levels in midline and lateral tectum including those with molecular masses similar to those of 
NG2 and neurocan, considered as responsible for the inhibitory activities of the astrocytic Neu7 cell line (Fidler et al. 1999) and reactive astrocytes (Asher et al. 2000), respectively. It would be of interest to verify the control of axonal growth and guidance at the spinal cord (and midbrain tectum) dorsal midline development of reactive gliosis in neurocan knockout animals which, presumably, present no major changes in brain development (Zhou et al. 2001).

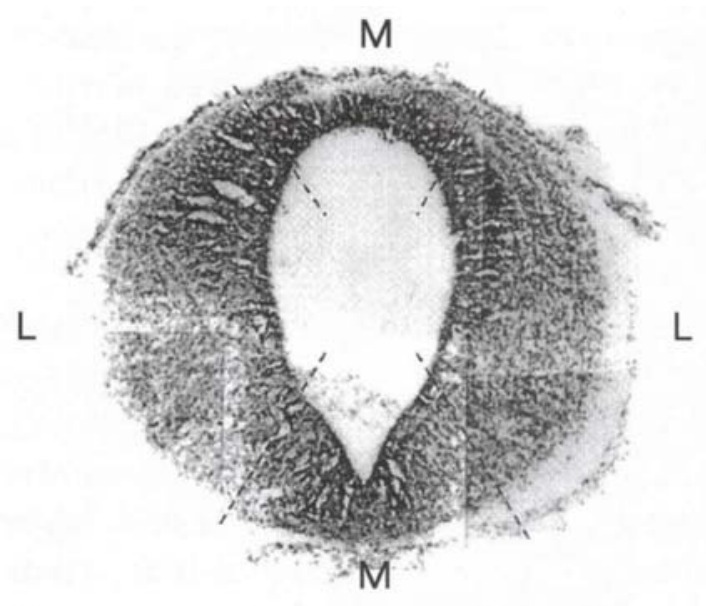

Fig. 1 - Photographic montage of a Nissl-stained thick coronal section through the E14 mouse midbrain to illustrate the regions removed for glial cultures (dashed lines - Cf. also Garcia-Abreu et al. 1995a,b, 2000). Maximal dorso-ventral dimension is about $1 \mathrm{~mm}$. Reproduced from Onofre et al. 2001. Braz J Med Biol Res 34: 251-258. Abbreviations: $\mathrm{M}=$ medial, $\mathrm{L}=$ lateral.

Attempts to verify whether the higher content of CS in medial midbrain astrocytes was responsible for their outgrowth-inhibitory properties did not confirm this hypothesis (Garcia-Abreu et al. 2000). Neurons growing on medial glia previously treated with chondroitinase $\mathrm{ABC}$ underwent only a very minor increase in the proportion of cells bearing neurites and in the total length of these processes, more precisely, in the length of the largest neurites (95th percentile). However, the same tendency was observed by the addition of an excess of CS4 (Mendes et al. 2002), the major GAG in midbrain glia (Onofre et al. 2001). Thus, it is possible that both the enzymatic treatment and the addi- tion of excess soluble CS disrupt CS-mediated binding of molecules that need not themselves be PGs (See also Emerling and Lander 1996). At present, there are no clues about the identity of such presumptive molecules since, for example, there is no excess of tenascin- $\mathrm{C}$ in medial astrocytes with respect to the outgrowth-promoting lateral astrocytes (Garcia-Abreu et al. 2000). It should be mentioned, in passing, that treatment of lateral astrocytes with chondroitinase $\mathrm{ABC}$ decreases noticeably their promotive ability for neuritic growth in comparison with the effect in medial astrocytes and that the excess of soluble CS-4 does not mimic as precisely this effect, causing more complex, concentrationdependent but non-linear effects (Mendes et al. 2002).

It has been occasionally argued that the true effects of astrocytic CSPGs could not possibly be ascertained in conventional cell cultures in which the extracellular CSPGs would not be retained at the cell surface and would be greatly diluted by the medium (Asher et al. 2000, Cf. also Ichijo and Kawabata 2001). The interpretation is that in three-dimensional cultures, as well as in the diminutive extracellular space of the mature brain, CSPGs would be trapped between the cells, where they would be in a position to interfere with access to neurite outgrowth-promoting molecules on astrocytes. That may well be true for the adult, injured brain and antagonizing it may represent a way to promote functional recovery after brain or spinal cord injury (Moon et al. 2001, Bradbury et al. 2002). However, the opposite effects of chondroitinase $\mathrm{ABC}$ on growth-modulating activities of lateral and medial glia points out to a heterogeneous distribution of CSPGs themselves in our system and/ or to attractive or repulsive proteins to which they attach. Again, it is interesting to recall that the DSD-1 proteoglycan (mouse homologue of phosphacan) displays opposing effects on neurite outgrowth dependent on neuronal lineage, showing a CS/ DS dependent growthpromoting effect on neurites of E-14 midbrain and E-18 hippocampal neurons and a growth-inhibitory effect on embryonic dorsal root ganglion neurons 
TABLE I

Distribution of amounts of ${ }^{35} \mathrm{~S}$-labeled CS glycosaminoglycans from the pericellular (P) and extracellular (E) compartments of medial and lateral glial cultures.

\begin{tabular}{l|c|c|c|c}
\hline & & $\begin{array}{c}\mathrm{P}+\mathrm{E} \\
(\text { countings })\end{array}$ & $\begin{array}{c}\text { Ratio P/E } \\
(\mathrm{P}+\mathrm{E})\end{array}$ & Ratio M/L \\
\hline & Lateral & 2549 & 0.03 & \\
\hline $\mathrm{CS}$ & & & & 1.65 \\
\hline & Medial & 4201 & 0.42 & \\
\hline
\end{tabular}

(Faissner et al. 1994, Garwood et al. 1999).

\section{Non-Neuronal HSPGs Modulation of Neurite Growth at the Midline and Other Sites}

Little information is available on the older literature for a role of HSPGs on axon growth and guidance at the midline. Both the older and the current literature have emphasized the idea that HSPGs play a supportive role to axon growth (Hantaz-Ambroise et al. 1987, Verna et al. 1989, Riopelle and Dow 1990, Halfter et al. 1997, Dow and Wang 1998, Yamaguchi 2001), irrespective of contrary evidence of a HSPG as a substrate in vitro (Halfter et al. 1997). This uniformity of thought is surprising in view of the conflicting concepts of the role played by HS in other events such as tumor growth and metastasis (Cf. Liu et al. 2002 and references therein). As already emphasized by Turnbull and coworkers (2001), there has been an increasing realization that specific sequences in the HS chains are designed for selective interactions with many proteins and that HS functions as a new class of multifunctional cell regulator.

In spite of most of the early in vitro studies reporting an outgrowth-promoting activity of HSPGs. Review: (Dow and Wang 1998) there were examples in which HS-binding proteins were viewed as antagonistic to neurite extension (Tobey et al. 1985). Ten years after the study of Tobey and coworkers (1985), this dependence on the substrate was persuasively demonstrated by Dou and Levine (1995) who showed that the percentage of cerebellar neu- rons with neurites and the length of these neurites on a substratum of $\mathrm{L} 1+\mathrm{HS}(10 \mu \mathrm{g} / \mathrm{ml})$ was half of the respective values for the same neurons on a $\mathrm{L} 1$ (only) substratum. For comparison, similar values for CS-6 were obtained only after adding this GAG at 100 fold concentration $(\mathrm{L} 1+\mathrm{CS}-6(1 \mathrm{mg} / \mathrm{ml}))$.

In our work on the compartmental distributions of GAGs in medial and lateral midbrain glia, it was verified, but not emphasized, that sulfated HS (or, at least, its degree of sulfation) was about 1.5 higher than sulfated CS in both cultures and that sulfated HS in medial astrocytes was 3.25fold higher than in lateral astrocytes (Garcia-Abreu et al. 1996). Interestingly, the percentage of the lane's radioactivity of radioiodinated core proteins was about fourfold higher for CSPGs than HSPGs in neonatal hamster optic tectum with the latter being apparently due to syndecan 3 and glypican 1 and to very low levels of a soluble HSPG (Hoffman-Kim et al. 1998).

Treatment of $\mathrm{M}$ glial cultures with heparitinase before and during coculturing caused a dramatic reversal of $\mathrm{M}$ glia outgrowth-inhibitory capacity (Garcia-Abreu et al. 2000). The proportion of midbrain neurons cultured onto heparitinase-treated $\mathrm{M}$ astrocytes that produced two or more neurites rose from about $40 \%$ to more than $80 \%$ and the median value of their total length increased more than 1.5fold (Fig. 2). A dramatic change also occurred in their maximal total length that became more than twice as high as in the control neurons, grown on untreated $\mathrm{M}$ cultures. There were also changes in cocultures including L glia but they appear minor in 
TABLE II

Distribution of amounts of ${ }^{35} \mathrm{~S}$-labeled HS glycosaminoglycans from the pericellular (P) and extracellular (E) compartments of medial and lateral glial cultures.

\begin{tabular}{l|c|c|c|c}
\hline & & $\begin{array}{c}\text { P+E } \\
\text { (countings) }\end{array}$ & Ratio P/E & Ratio M/L \\
\hline & Lateral & 2161 & 2.5 & \\
\hline HS & & & & 3.25 \\
\hline & Medial & 7034 & 2.5 & \\
\hline
\end{tabular}

comparison to those occurring in neurons cultured onto M glia.

The dramatic changes occurring in $\mathrm{M}$ glia cocultures raise many questions such as (1) Could the changes in M glial cultures be merely due to removal of axonal HSPGs? (2) Are there changes in the glial surfaces that might give clues to the mechanism(s) involved? (3) If the answer to question 1 is "No", which are the candidates glial HSPG and which hypothetical mechanisms could be involved in causing inhibition of neurite growth?

It is highly unlikely that removal of HS from axonal HSPGs are the main object of the changes since heparitinase treatment of neurons cultured on laminin caused no significant change in the number or length of neurites with respect to the control (Garcia-Abreu et al. 2000).

With regard to question 2, we approached it by using atomic force microscopy (AFM). AFM provides morphological information, makes it possible to infer the physical properties of the analyzed samples, and has been used to study the cell surface elasticity and viscosity and cytoskeleton dynamics in many cells including neuron and glial cells (Butt et al. 1990, Radmacher et al. 1992, Henderson and Sakaguchi 1993, Parpura et al. 1993, Braet et al 1998, Weyn et al. 1998). To be able to analyze the cell surfaces, glial cultures lightly fixed with paraformaldehyde were used and, in the case of $\mathrm{L}$ glia, results were consistent with scanning electron microscopic results found in the literature (Collins et al. 1979).
The outgrowth-promoting $\mathrm{L}$ astrocytes showed a highly corrugated surface, with closely-spaced protrusions measuring characteristically $0.3-$ $0.5 \mu \mathrm{m}$ diameter and $0.2-0.3 \mu \mathrm{m}$ height, and displayed a strong interaction between the protrusions and the scanning tip so that the protrusions were dragged by the tip along the scan direction. By contrast, the surface of $\mathrm{M}$ astrocytes appeared to be devoid of such protrusions and was recovered by a fibrillar network, never detected in L astrocytes, with fibrils formed by straight rather then undulated segments which were not organized in any particular direction. Fibrils could be characterized as $0.12 \mu \mathrm{m}$ wide and $0.5-2.0 \mu \mathrm{m}$ long.

Treatment of $\mathrm{L}$ and $\mathrm{M}$ astrocytes with different enzymes, including chondroitinase $\mathrm{ABC}$ caused no change in their surfaces whereas treatment with heparitinase I resulted in the acquisition of an L-like profile by M cells. Together with our previous works on the distribution of the cell surface associatedmolecules, these findings may indicate that such different topographic and physical properties could reflect the complexity of network molecules on $\mathrm{L}$ and $M$ surfaces. Furthermore, they also indicate that the distribution of HSPG(s) may be responsible for glia-neuronal interaction abilities.

Neither the formation of a fibrillary network nor its depletion by heparitinase are clearly understood. It is highly unlikely that the fibrils involve the polysialic acid units of the neural cell adhesion molecule N-CAM, which form filament bundle networks (Toikka et al. 1998) since E-14 mid- 


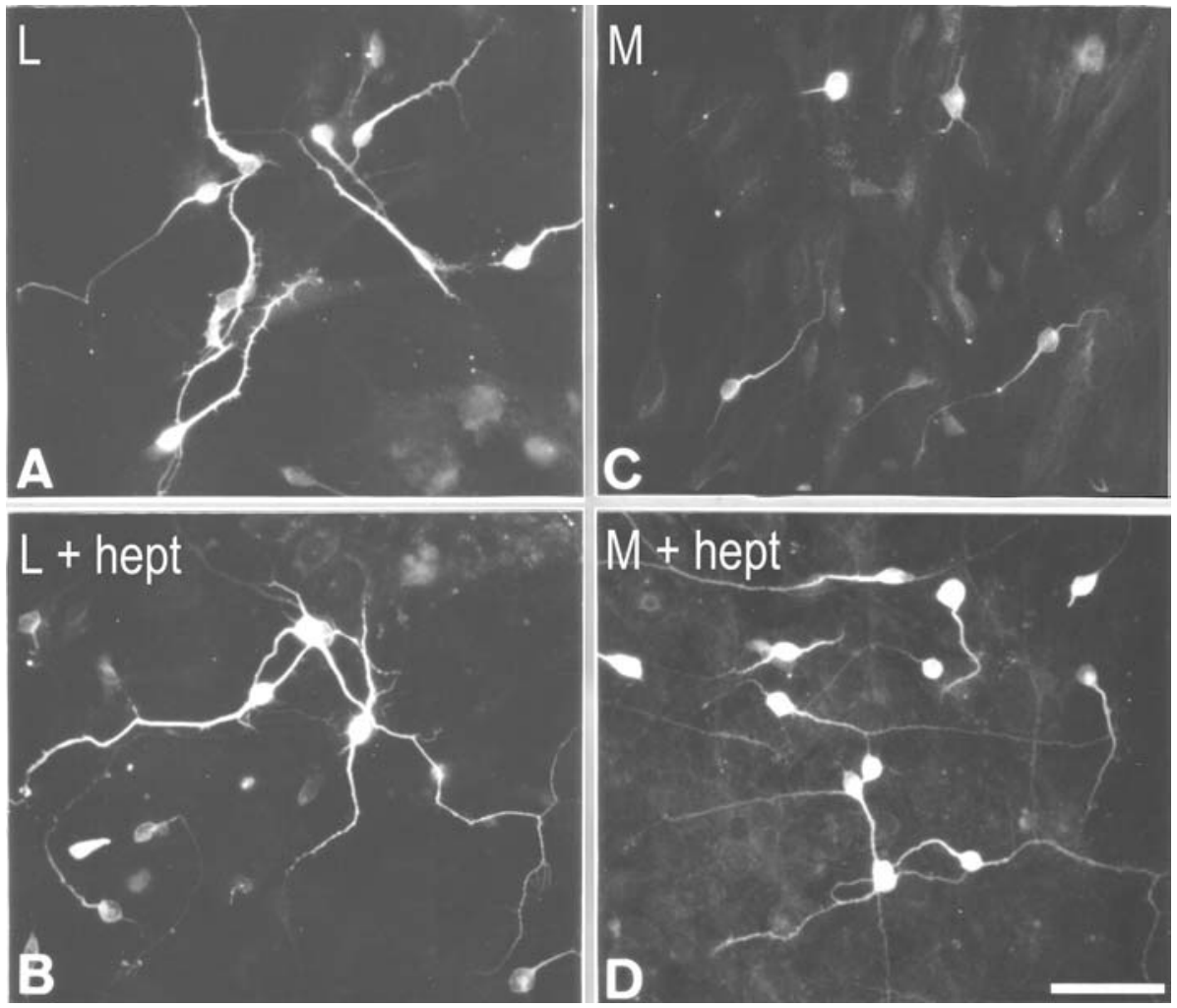

Fig. 2 - Photomicrographs showing predominant morphologies of MAP2-stained E14 midbrain neurons after culturing for $24 \mathrm{~h}$ onto lateral (A, B) and medial (C, D) astrocytes. A and C show neurons grown onto a substrate of L (A) or M astrocytes (C) without enzymatic treatment whereas B and D show the results of heparitinase I (hept) degradation. Notice that hept treatment reverts the inhibitory properties of $\mathrm{M}$ astrocytes (D) as also shown by $\beta 3$ tubulin staining (Fig. 5 in Garcia-Abreu et al. 2000). Scale bar: $50 \mu \mathrm{m}$.

brain neurons but not our cultured astrocytes are immunoreactive for syalilated N-CAM (Garcia-Abreu et al. 1995b). It is obvious that heparan sulfate is the major component of these fibrils or it is important for their stability. It is known that some HSPG such as a high molecular weight HSPG isolated from the murine Engelbreth-Holm-Swarm tumor can self-assemble into dimers and lesser amounts of oligomers (Yurchenco et al. 1987) but the binding region is opposite the origin of HS chains rather than in the chains. The occurrence of fibrils obviously evokes the occurrence pathological extracellular deposits of fibrillar $\beta$-amyloid and HSPGs. It is known that several HSPGs such as perlecan, agrin, glypican, syndecans 2 and 3, and collagen XVIII are found in senile plaques, ghost tan- gles and other deposits in Alzheimer disease (Snow et al. 1994, Verbeek et al. 1999, Van Horssen et al. 2002). Furthermore, an electromicroscopical and immunocytochemistry study of brains affected by Alzheimer's disease has shown that certain $\mathrm{A} \beta$-immunolabeled processes may contain GFAPreactive filaments (Kurt et al. 1999). Furthermore, it is known that $\beta$-amyloid peptides inhibit cell adhesion and neurite outgrowth (Postuma et al. 2000), thus, raising the possibility that the fibrillar network holds $\beta$-amyloid peptides and may cause the outgrowth inhibitory effects. However, it cannot be ruled out that HS takes part in the formation of other types of fibrils, e.g., a type that does not involve $\beta$ amyloid protein precursor. In fact, work employing the small protein acylphosphatase has suggested 

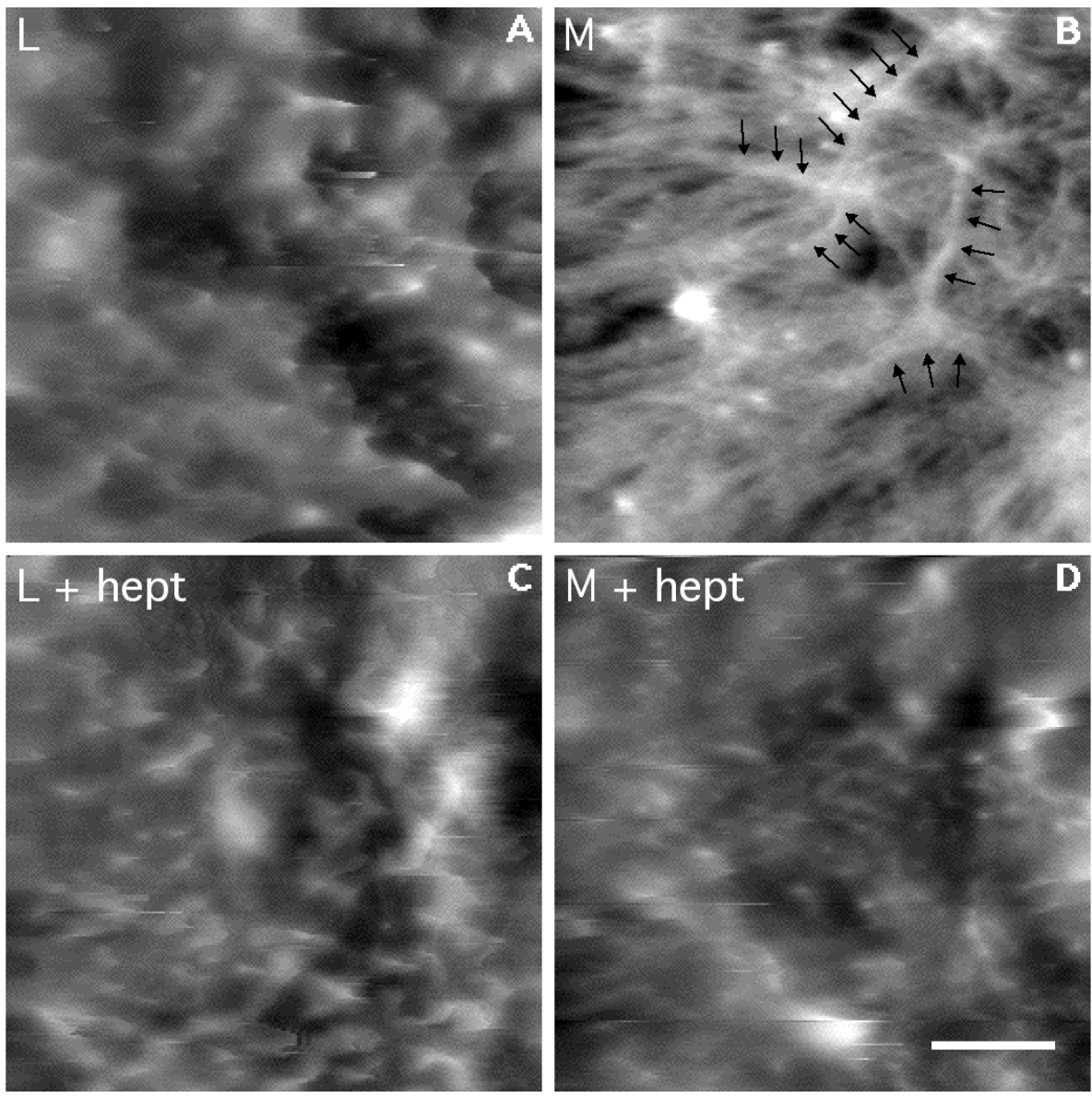

Fig. 3 - Differential functional morphology of the surface of lateral (L) and medial (M) midbrain astrocytes and changes induced by heparitinase (hept). Atomic force microscopy images of L astrocytes (A, C) or M astrocytes (B, D) in control cultures (A, B) or in hept-treated cultures (C, D). Observe that the surface of the L astrocyte is highly corrugated (A) whereas the surface of the M astrocyte (B) is recovered by a fibrillar network (arrowheads), with fibrils that may converge in some points. Heparitinase treatment of $\mathrm{M}$ astrocytes (D) changes their surface in parallel in parallel with the change in permissivity to neuritic growth. Modified from Weissmüller et al. 2000. Neurosci Res 38: 217-220. Scale bar: $2 \mu \mathrm{m}$.

that formation of amyloid-like fibrils is not restricted to a small number of protein sequences but may be a property common to many, if not all, natural polypeptide chains under appropriate conditions (Chiti et al. 1999).

An alternative, but not mutually exclusive, explanation is that the non-permissivity of $\mathrm{M}$ glia for neurite growth depends on a repulsive activity of the slit protein in association with cell-surface heparan sulfate, as demonstrated for olfactory axons in explant cultures (Hu 2001). Several midline glial spe- cializations such as the roof and floor plates and the chiasmatic glial palisade express slit (Erskine et al. 2000, Zou et al. 2000, Brose and Tessier-Lavigne 2000) and that may occur in the presumptive derivatives of the midbrain homologues in culture. There is also convincing evidence that glypican-1 binds slit (Liang et al. 1999, Ronca et al. 2001) and there is no insurmountable obstacle to the formation of a complex of slit/ glypican and a (neuronal) robo receptor since glypican-1 is expressed by astrocytes (Bansal et al. 1996) and is shed from the cell sur- 
face (Winkler et al. 2002). Additionally, syndecans 2 and 4, that may also be shed, are heavily expressed in cultured astrocytes (Bansal et al. 1996).

The relevance of heparan sulfates to the modulation of axon growth and guidance at the midline may be much higher than usually believed. Heparan is expressed by SSEA-1 hypothalamic neurons in the mouse and may be involved in changes in age-related fiber order in the optic chiasm and chiasm/ optic tract transition (Chung et al. 2001). Furthermore, very relevant findings on the relations of HSPGs to midline crossing have been found in the exposed, live brain of Xenopus embryos. Administration of exogenous heparin or perlecan-FGF2 to the optic tract of stages 37-40 embryos caused advanced optic axons to cross the dorsal midline via the posterior commissure (Walz et al. 1997) in addition to other navigational errors of bypassing of the optic tectum, with fibers either growing around the anterior or anterior/ ventral tectal margins. Heparitinase treatment and removal of axonal HS at these late stages also caused errors in axon guidance including erroneous crossing of the midline. Actual reduction of axonal growth was observed only in early embryos (stages 32-37) in which heparitinase caused a "shortening" of the optic tract that could be reversed by addition of FGF-2 but without correction of the navigational errors (Walz et al. 1997).

Significant new work has been done in the identification of the structural characteristics of HS that induce aberrant axon targeting such as the erroneous crossing at Xenopus dorsal diencephalon. Indeed this bypass-inducing activity has been correlated to distinct structures, particularly those containing a combination of 2-O- and 6- $O$-sulfate groups (Irie et al. 2002) and seems unrelated to N-sulfation, which is essential for FGF-2 signaling (Yamane et al. 1998). Thus, it has been hypothesized that 6$O$-sulfated HS in the dorsal diencephalon provides a crucial component of a repulsive signal that is essential for correct axonal guidance in Xenopus. It remains to be determined whether a homologue component is responsible for the contribution of heparan sulfate to the non-permissive role of the midline glia to the growth of midbrain neurites in a mammal.

\section{ACKNOWLEDGMENTS}

We thank Fabio Mendes for permission to cite unpublished work and apologize to the many colleagues whose work was not cited for space constraints. LAC would like to thank Drs. Rosalia Mendez-Otero and Helena Nader for an invitation to present parts of this work in SIMEC 2002. The excellent technical assistance of Sergio Luiz de Carvalho is gratefully acknowledged. This study was supported by grants from FAPERJ, CNPq, PRONEX, and Instituto do Milênio de Bioengenharia Tecidual.

\section{RESUMO}

Organismos com simetria bilateral precisam trocar informações entre os lados direito e esquerdo de seus corpos a fim de integrar insumos sensoriais e coordenar o controle motor. Assim, um importante ponto de escolha para axônios em desenvolvimento é a linha média do sistema nervoso central. O cruzamento deste ponto é influenciado por moléculas altamente conservadas filogeneticamente, solúveis ou ligadas a membranas, tais como a sub-família L1, laminina, netrinas, "slits", semaforinas, receptores tipo Eph e "ephrinas", etc. Além disso, existe grande quantidade de evidências circunstanciais para um papel dos proteoglicanos (PGs) ou suas metades glicosaminoglicanas (GAG) no crescimento e orientação de axônios, geralmente obtida em modelos simplificados. Um modelo de complexidade intermediária é o de co-culturas de neurônios jovens e tapetes (culturas confluentes) de astrócitos obtidos de setores medial e lateral do mesencéfalo embrionário de roedores, pouco após a formação de suas comissuras. A produção de neuritos nestas culturas revela que, independentemente da localização prévia dos neurônios no mesencéfalo, astrócitos mediais exercem um efeito inibitório ou não-permissivo sobre o crescimento de neuritos que se correlaciona com um maior teor tanto de heparan quanto de condroitin sulfato (HS e CS). O tratamento com liases de GAGs mostra efeitos minoritários de CS e revela um papel majoritário inibitório ou nãopermissivo para HS. Os resultados são discutidos em ter- 
mos do conhecimento atualmente disponível sobre ligações de HSPGs a proteínas interativas e enfatizam a importância de compreender os arranjos de polissacarídeos gliais, adicionalmente ao conjunto de suas proteínas, para melhor compreensão das interações neuro-gliais.

Palavras-chave: astrócitos, crescimento de axônios, heparan sulfato, matriz extra-celular, linha média, mesencéfalo.

\section{REFERENCES}

Anderson RB, Walz Holt CE and Key B. 1998. Chondroitin sulfates modulate axon guidance in embryonic Xenopus brain. Dev Biol 202: 235-243.

Anderson RB, Cooper HM, Jackson SC, Seaman C AND KEY B. 2000. DCC plays a role in navigation of forebrain axons across the ventral midbrain commissure in embryonic Xenopus. Dev Biol 217: 244-253.

Apkarian P, Bour LJ, Barth PG, Wenniger-Prick L AND Verbeeten B JR. 1995. Non-decussating retinal-fugal fibre syndrome. An inborn achiasmatic malformation associated with visuotopic misrouting, visual evoked potential ipsilateral asymmetry and nystagmus. Brain 118: 1195-1216.

Asher RA, Morgenstern DA, FidLer PS, AdCOCK KH, Oohira A, Braistead JE, Levine JM, Margolis RU, Rogers JH ANd FAwCETt JW. 2000. Neurocan is upregulated in injured brain and in cytokine-treated astrocytes. J Neurosci 20: 2427-2438.

Ba-Charvet KTN and Chédotal A. 2002. Role of Slit proteins in the vertebrate brain. J Physiol (Paris) 96: 91-98.

Bagri A, Marin O, Plump as, Mak J, Pleasure SJ, Rubenstein JLR and Tessier-Lavigne M. 2002. Slit proteins prevent midline crossing and determine the dorsoventral position of major axonal pathways in the mammalian forebrain. Neuron 33: 233-248.

Bandtlow CE and Zimmermann DR. 2000. Proteoglycans in the developing brain: New conceptual insights for old proteins. Physiol Rev 80: 1267-1290.

Bansal R, Kumar M, Murray K and Pfeiffer SE. 1996. Developmental and FGF-2-mediated regulation of syndecans (1-4) and glypican in oligodendrocytes. Mol Cell Neurosci 7: 276-288.

Barnea G, Grumet M, Milev P, Silvennoinen O, Levy JB, SAP J AND Schlessinger J. 1994. Recep- tor tyrosine phosphatase beta is expressed in the form of proteoglycan and binds to the extracellular matrix protein tenascin. J Biol Chem 269: 14349-14352.

Barradas PC, Cavalcante LA, MendeZ-Otero R and VIEIRA AM. 1989. Astroglial differentiation in the opossum superior colliculus. Glia 2: 103-111.

Bennett KL, Bradshaw J, Youngman T, Rodgers J, Greenfield B, Aruffo A ANd Linsley PS. 1997. Deleted in colorectal carcinoma (DCC) binds heparin via its fifth fibronectin type III domain. J Biol Chem 272: 26940-26946.

BERNHARDT RR. 1994. Ipsi- and contralateral commissural growth cones react differently to the cellular environment of the ventral zebrafish spinal cord. J Comp Neurol 350: 122-132.

BhIDE PG AND Frost DO. 1999. Intrinsic determinants of retinal axon collateralization and arborization patterns. J Comp Neurol 411: 119-129.

Bovolenta P And DodD J. 1990. Guidance of commissural growth cones at the floor plate in embryonic rat spinal cord. Development 109: 435-447.

Bradbury EJ, Moon LDF, Popat RJ, King VR, BenNett GS, Patel PN, Fawcett JW and McMahon SB. 2002. Chondroitinase ABC promotes functional recovery after spinal cord injury. Nature 416 : 636-640.

Braet F, Rotsch C, Wisse E and Radmacher M. 1998. Comparison of fixed and living liver endothelial cells by atomic force microscopy. Appl Phys A 66: S575S578.

Brose K and Tessier-Lavigne M. 2000. Slit proteins: key regulators of axon guidance, axonal branching, and cell migration. Cur Opin Neurobiol 10: 95-102.

Brümmendorf T, Kenwrickt S and Rathjen FG. 1998. Neural cell recognition molecule L 1: from cell biology to human hereditary brain malformations. Cur Opin Neurobiol 8: 87-97.

Bullock SL, Fletcher JM, Beddington RS AND WiLSON VA. 1998. Renal agenesis in mice homozygous for a gene trap mutation in the gene encoding heparan sulfate 2-sulfotransferase. Genes Dev 12: 18941906.

Butt HJ, Wolff EK, Gould SA, Dixon Northern B, Peterson CM and Hansma PK. 1990. Imaging cells with the atomic force microscope. J Struct Biol 105: 54-61. 
Castellani V, Chédotal A, Schachner M, FaivreSarrailh C and Rougon G. 2000. Analysis of the L1-deficient mouse phenotype reveals cross-talk between Sema3A and L1 signaling pathways in axonal guidance. Neuron 27: 237-249.

Chen H, Bagri A, Zupicich JA, Zou Y, Stoeckli E, Pleasure SJ, Lowenstein DH, Skarnes WC, Chedotal A and Tessier-Lavigne M. 2000. Neuropilin-2 regulates the development of selective cranial and sensory nerves and hippocampal mossy fiber projections. Neuron 25: 43-56.

Chiti F, Webster P, Taddei N, Clark A, Stefani M, Ramponi G, Christopher M and Dobson CM. 1999. Designing conditions for in vitro formation of amyloid protofilaments and fibrils. Proc Nat Acad Sci USA 96: 3590-3594.

Choi S, Jeong J, Kim T and Park S. 1999. Characterization of ephrin-A1 and ephrin-A4 as ligands for the EphA8 receptor protein tyrosine kinase. Mol Cells 9: 440-445.

Chung KY, Taylor JS, Shum DK and Chan SO. 2000. Axon routing at the optic chiasm after enzymatic removal of chondroitin sulfate in mouse embryos. Development 127: 2673-2683.

Chung KY, Leung KM, Lin L and Chan SO. 2001. Heparan sulfate proteoglycan expression in the optic chiasm of mouse embryos. J Comp Neurol 436: $236-247$.

Cohen NR, Taylor JSH, Scott LB, Guillery RW, Soriano P AND Furley AJW. 1998. Errors in corticospinal axon guidance in mice lacking the neural cell adhesion molecule L1. Curr Biol 8: 26-33.

Colamarino SA and Tessier-Lavigne M. 1995. The axonal chemoattractant Netrin-1 is also a chemorepellent for trochlear motor axons. Cell 81: 621-629.

Collins VP, Brunk UT, Fredriksson BA ANd WesterMARK B. 1979. The fine structure of growing human glia and glioma cells. Whole cell preparations. Acta Pathol Microbiol Scand [A] 87: 29-36.

Dahme M, Bartsch U, Martini R, Anliker B, Schachner M AND Mantei N. 1997. Disruption of the mouse L1 gene leads to malformations of the nervous system. Nat Genet 17: 346-349.

Dodd J, Morton SB, Karagogeos D, Yamamoto M AND JESSELL TM. 1988. Spatial regulation of ax- onal glycoprotein expression on subsets of embryonic spinal neurons. Neuron 1: 105-116.

Dottori M, Hartley L, Galea M, Paxinos G, Polizzotto M, Kilpatrick T, Bartlett PF, Murphy M, Kontgen F And Boyd AW. 1998. EphA4 (Sek1) receptor tyrosine kinase is required for the development of the corticospinal tract. Proc Natl Acad Sci USA. 95: $13248-13253$.

Dou CJ And Levine JM. 1995. Differential effects of glycosaminoglycans on neurite growth on laminin and L1 substrates. J Neurosci 15: 8053-8066.

Dow KE AND WANG W. 1998. Cell biology of astrocyte proteoglycans. CMLS. Cell Mol Life Sci 54: 567581.

EASTER SS JR AND SCHMIDT JT. 1977. Reversed visuomotor behavior mediated by induced ipsilateral retinal projections in goldfish. J Neurophysiol 40: 1245-1254.

EMERLING DE AND LANDER AD. 1996. Inhibitors and promoters of thalamic neuron adhesion and outgrowth in embryonic neocortex: functional association with chondroitin sulfate. Neuron 17: 10891100.

Erskine L, Williams SE, Brose K, Kidd T, Rachel RA, Goodman CS, Tessier-Lavigne M and Mason CA. 2000. Retinal ganglion cell axon guidance in the mouse optic chiasm: expression and function of robos and slits. J Neurosci 20: 4975-4982.

Faissner A, Clement A, Lochter A, Streit A, MANDL C AND SCHaChNer M. 1994. Isolation of a neural chondroitin sulfate proteoglycan with neurite outgrowth promoting properties. J Cell Biol 126: 783-799.

Fazeli A, Dickinson SL, Hermiston ML, Tighe RV, Steen RG, Small CG, Stoeckli ET et al. 1997. Phenotype of mice lacking functional Deleted in Colorectal Carcinoma (DCC) gene. Nature 386: 796-804.

Fernaud-Espinosa I, Nieto-Sampedro M And BovoLENTA P. 1996. Developmental distribution of glycosaminoglycans in embryonic rat brain: Relationship to axonal tract formation. J Neurobiol 30: 410424.

Fidler PS, Schuette K, Asher RA, Dobbertin A, Thornton SR, Calle-Patino Y, Muir E, Levine 
JM, Geller HM, Rogers JH, Faissner A AND FAWCETT JW. 1999. Comparing astrocytic cell lines that are inhibitory or permissive for axon growth: the major axon-inhibitory proteoglycan is NG2. J Neurosci 19: 8778-8788.

Fitch MT AND Silver J. 1997. Glial cell extracellular matrix: boundaries for axon growth in development and regeneration. Cell Tissue Res 290: 379-384.

Frost DO, So KF And Schneider GE. 1979. Postnatal development of retinal projections in Syrian hamsters: a study using autoradiographic and anterograde degeneration techniques. Neuroscience 4: 1649-1677.

Garcia-Abreu J, Moura Neto V, Carvalho SL and Cavalcante LA. 1995a. Regionally specific properties of midbrain glia: I. Interactions with midbrain neurons. J Neurosci Res 40: 471-477.

Garcia-Abreu J, Cavalcante LA and Moura Neto V. 1995b. Differential patterns of laminin expression in lateral and medial midbrain glia. NeuroReport 6: 761-764.

Garcia-Abreu J, Silva LCF, Tovar FF, Onofre GR, Cavalcante LA and Moura Neto V. 1996. Compartmental distribution of sulfated glycosaminoglycans in lateral and medial midbrain astroglial cultures. Glia 17: 339-344.

Garcia-Abreu J, Mendes FA, Onofre GR, Freitas MS, Silva LCF, Moura Neto V and Cavalcante LA. 2000. Contribution of heparan sulfate to the nonpermissive role of the midline glia to the growth of midbrain neurites. Glia 29: 260-272.

Garwood J, Schnadelbach O, Clement A, Schutte K, BaCh A And Faissner A. 1999. DSD-1 proteoglycan is the mouse homolog of phosphacan and displays opposing effects on neurite outgrowth dependent on neuronal lineage. J Neurosci 19: 3888-3899.

George SE, Simokat K, Hardin J and Chisholm AD. 1998. The VAB-1 Eph receptor tyrosine kinase functions in neural and epithelial morphogenesis in $\mathrm{C}$. elegans. Cell 92: 633-643.

Halfter W, Schurer B, Yip J, Yip L, Tsen G, Lee JA AND Cole GJ. 1997. Distribution and substrate properties of agrin, a heparan sulfate proteoglycan of developing axonal pathways. J Comp Neurol 383: $1-17$.
Hamre KM, Keller-Peck CR, Campbell RM, PeterSon AC, Mullen RJ And Goldowitz D. 1996. Annexin IV is a marker of roof and floor plate development in the murine CNS. J Comp Neurol 368: 527537.

HantaZ-Ambroise D, Vigny M and Koenig J. 1987. Heparan sulfate proteoglycan and laminin mediate two different types of neurite outgrowth. J Neurosci 7: 2293-2304.

Harroch A, Palmeri M, Rosenbluth J, Custer A, Okigaki M, Shrager P, Blum M, Buxbaum JD AND SCHLESSINGER J. 2000. No obvious abnormality in mice deficient in Receptor Protein Tyrosine Phosphatase $\beta$. Mol Cell Biol 20: 7706-7715.

Hartmann U and Maurer P. 2001. Proteoglycans in the nervous system - the quest for functional roles in vivo. Matrix Biology 20: 23-35.

Henderson E AND SAKaguchi D. 1993. Imaging FActin in fixed glial cells with a combined optical fluorescence/atomic force microscope. Neuroimage 1: 145-150.

Henke-Fahle S, Beck KW and Püschel A. 2001. Differential responsiveness to the chemorepellent Semaphorin 3A distinguishes ipsi- and contralaterally projecting axons in the chick midbrain. Dev Biol 237: 381-397.

Henkemeyer M, Orioli D, Henderson JT, SaXton TM, Roder J, Pawson T And KleIn R. 1996. Nuk controls pathfinding of commissural axons in the mammalian central nervous system. Cell 86: 35-46.

Hoffman-Kim D, Lander AD and Jhaveri S. 1998. Patterns of chondroitin sulfate immunoreactivity in the developing tectum reflect regional differences in glycosaminoglycan biosynthesis. J Neurosci 18 : 5881-5890.

Holder N AND Klein R. 1999. Eph receptors and ephrins: effectors of morphogenesis. Development 126: 2033-2044.

Hopker VH, Shewan D, Tessier-Lavigne M, Poo M AND Holt C. 1999. Growth-cone attraction to netrin1 is converted to repulsion by laminin-1. Nature 401: 69-73.

Hu H. 2001. Cell-surface heparan sulfate is involved in the repulsive guidance activities of Slit 2 protein. Nature Neurosci. 4: 695-701. 
ICHIJO H AND Kawabata I. 2001. Roles of the telencephalic cells and their chondroitin sulfate proteoglycans in delimiting an anterior border of the retinal pathway. J Neurosci 21: 9304-9314.

IMONDI R AND KAPRIELIAN Z. 2001. Commissural axon pathfinding on the contralateral side of the floor plate: a role for B-class ephrins in specifying the dorsoventral position of longitudinally projecting commissural axons. Development 128: 4859-4871.

Imondi R, Wideman C And Kaprielian Z. 2000. Complementary expression of transmembrane ephrins and their receptors in the mouse spinal cord: a possible role in constraining the orientation of longitudinally projecting axons. Development 127: 1397-1410.

Iozzo RV. 1998. Matrix proteoglycans: From molecular design to cellular function. Annu Rev Biochem 67: $609-652$.

Irie A, Yates EA, Turnbull JE and Holt CE. 2002. Specific heparan sulfate structures involved in retinal axon targeting. Development 129: 61-70.

JHAVERI S. 1993. Midline glia of the tectum: a barrier for developing retinal axons. Perspect Dev Neurobiol 1: 237-243.

JHAVERi S AND HoFFMAN-Kim D. 1996. Unilateral containment of retinal axons by tectal glia: a possible role for sulfated proteoglycans. Prog Brain Res 108: 136-148.

JHAVeri S, Edwards MA AND Schneider GE. 1991. Initial stages of retinofugal axon development in the hamster: evidence for two distinct modes of growth. Exp Brain Res 87: 371-382.

Kageyama GH and Robertson RT. 1993. Transcellular retrograde labeling of radial glial cells with WGAHRP and DiI in neonatal rat and hamster. Glia 9: 70-81.

Kahane N and Kalcheim C. 1998. Identification of early postmitotic cells in distinct embryonic sites and their possible roles in morphogenesis. Cell Tissue Res 294: 297-307.

Kalil K, Szebenyi G and Dent EW. 2000. Common mechanisms underlying growth cone guidance and axon branching. J Neurobiol 44: 145-158.

Kamiguchi H, HLavin ML and Lemmon V. 1998. Role of L1 in Neural Development: What the Knockouts Tell Us. Mol Cell Neurosci 12: 48-55.
Kappler J, Franken S, Junghans U, Hoffmann R, Linke T, Muller HW and Koch KW. 2000. Glycosaminoglycan-binding properties and secondary structure of the C-terminus of netrin- 1 . Biochem Biophys Res Commun 271: 287-291.

Kaprielian Z, Runko E and Imondi R. 2001. Axon guidance at the midline choice point. Dev Dyn 221: 154-181.

KingsBury BF. 1930. The developmental significance of the floor plate of the brain and spinal chord. J Comp Neurol 50: 177-207.

Knöll B And Drescher U. 2002. Ephrin-As as receptors in topographic projections. Trends Neurosci 25: 145-149.

Kullander K, Croll SD, Zimmer M, Pan L, McClain J, Hughes V, Zabski S, DeChiara TM, Klein R, Yancopoulos GD and Gale NW. 2001. Ephrin-B3 is the midline barrier that prevents corticospinal tract axons from recrossing, allowing for unilateral motor control. Genes Dev 15: 877-888.

Kurt MA, Davies DC And KidD M. 1999. $\beta$ etaAmyloid immunoreactivity in astrocytes in Alzheimer's disease brain biopsies: an electron microscope study. Exp Neurol 158: 221-228.

KuYPers HGJM. 1981. Motor control. In BroOKHART JM AND Mountcastle VB (eds.), Handbook of Physiology, Section 1: The Nervous System, Bethesda: American Physiological Society.

LANDER AD. 1993. Proteoglycans in the nervous system. Curr Opin Neurobiol 3: 716-723.

Lander A, Nakato H, Selleck SB, Turnbull JE and CoAтн C. 1999. Cell surface proteoglycans in signaling and development, HFSP, Strasbourg, 215 pp.

Lefrançois T, Fages C, Peschanski M and Tardy M. 1997. Neuritic outgrowth associated with astroglial phenotypic changes induced by anti-sense Glial Fibrillary Acidic Protein (GFAP) mRNA in injured neuron-astrocyte cocultures. J Neurosci 17: 4121-4128.

Liang Y, Annan RS, Carr SA, Popp S, Mevissen M, Margolis RK and Margolis RU. 1999. Mammalian homologues of the Drosophila slit protein are ligands of the heparan sulfate proteoglycan glypican1 in brain. J Biol Chem 274: 17885-17892.

LIESI P AND SILVER J. 1988. Is astrocyte laminin involved 
in axon guidance in the mammalian CNS? Dev Biol 130: 774-785.

Lin X And Perrimon N. 1999. Dally cooperates with Drosophila Frizzled 2 to transduce Wingless signalling. Nature 400: 281-284.

Lin X, Buff EM, Perrimon N And Michelson AM. 1999. Heparan sulfate proteoglycans are essential for FGF receptor signaling during Drosophila embryonic development. Development 126: 3715-3723.

Litwack ED, Stipp CS, Kumbasar A AND LANDER AD. 1994. Neuronal expression of glypican, a cellsurface glycosylphosphatidylinositol-anchored heparan sulfate proteoglycan, in the adult rat nervous system. J Neurosci 14: 3713-3724.

Liu D, Shriver Z, Venkataraman G, El Shabrawi Y AND SasiseKhaRan R. 2002. Tumor cell surface heparan sulfate as cryptic promoters or inhibitors of tumor growth and metastasis. Proc Natl Acad Sci USA 99: 568-573.

LUCKENBILL-EDDS L. 1997. Laminin and the mechanism of neuronal outgrowth. Brain Res Rev 23: 1-27.

Lustig M, Erskine L, Mason CA, Grumet M and SAKURAI T. 2001. Nr-CAM expression in the developing mouse nervous system: ventral midline structures, specific fiber tracts, and neuropilar regions. J Comp Neurol 434: 13-28.

Marcus RC And Mason CA. 1995. The first retinal axon growth in the mouse optic chiasm: Axon patterning and the cellular environment. J Neurosci 15: 63896402 .

Marcus RC, Blazeski R, Godement P and Mason CA. 1995. Retinal axon divergence in the optic chiasm: uncrossed axons diverge from crossed axons within a midline glial specialization. J Neurosci 15: 37163729.

Marcus RC, Mathews GA, Gale NW, Yancopoulos GD AND Mason. 2000. Axon guidance in the mouse optic chiasm: Retinal neurite inhibition by ephrin "A"-expressing hypothalamic cells in vitro. Dev Biol 221: 132-147.

Mason CA and Sretavan DW. 1997. Glia, neurons, and axon pathfinding during optic chiasm development. Curr Opin Neurobiol 7: 647-653.

Maurel P, Rauch U, Flad M, Margolis RK and Margolis RU. 1994. Phosphacan, a chondroitin sul- fate proteoglycan of brain that interacts with neurons and neural cell-adhesion molecules, is an extracellular variant of a receptor-type protein tyrosine phosphatase. Proc Natl Acad Sci U S A 91: 2512-2516.

McCabe CF and Cole GJ. 1992. Expression of the barrier-associated proteins EAP-300 and claustrin in the developing nervous system. Dev Brain Res 70: 9-24.

Mendes F, Onofre C, Silva lC, Cavalcante LA and Garcia-Abreu J. 2002. The concentrationdependent actions of glial chondroitin sulfate on the neuritic growth of midbrain neurons. Submitted.

Mendez-Otero R and Santiago MF. 2001. Functional role of a glycolipid in directional movements of neurons. An Acad Bras Cienc 73: 221-229.

Mendez-Otero R, Cavalcante LA, Rocha-Miranda CE, Bernardes RF and Barradas PC. 1985. Growth and restriction of the ipsilateral retinocollicular projection in the opossum. Dev Brain Res 18: $199-210$

Meyer-Puttlitz B, Junker E, Margolis RU AND MARgolis RK. 1996. Chondroitin sulfate proteoglycans in the developing central nervous system. II. Immunocytochemical localization of neurocan and phosphacan. J Comp Neurol 366: 44-54.

Milev P, Friedlander DR, Sakurai T, Karthikeyan L, Flad M, Margolis RK, Grumet M and MargoLIS RU. 1994. Interactions of the chondroitin sulfate proteoglycan phosphacan, the extracellular domain of a receptor-type protein tyrosine phosphatase, with neurons, glia, and neural cell adhesion molecules. J Cell Biol 127: 1703-1715.

Milev P, Maurel P, Haring M, Margolis RK and MARgolis RU. 1996. TAG-1/axonin-1 is a highaffinity ligand of neurocan, phosphacan/proteintyrosine phosphatase- $\xi$ / $\beta$, and N-CAM. J Biol Chem 271: 15716-15723.

Ming G-L, Song H-J, Berninger B, Holt CE, TessierLavigne M ANd Poo M-M. 1997. cAMP-dependent growth cone guidance by Netrin-1. Neuron 19: $1225-1235$.

Moon LGF, Asher RA, Rhodes KE And Fawcett JW. 2001. Regeneration of CNS axons back to their target following treatment of adult rat brain with chonddoitinase ABC. Nat Neurosci 4: 465-466. 
Mori K, IKeda J and Hayaishi O. 1990. Monoclonal antibody R2D5 reveals midsagittal radial glial system in postnatally developing and adult brainstem. Proc Natl Acad Sci USA 87: 5489-5493.

Nakagawa S, Brennan C, Johnson KG, Shewan D, Harris WA AND Holt CE. 2000. Ephrin-B regulates the Ipsilateral routing of retinal axons at the optic chiasm. Neuron 25: 599-610.

Niederöst BP, Zimmermann DR, Schwab ME ANd BANDTLOW CE. 1999. Bovine CNS myelin contains neurite growth-inhibitory activity associated with chondroitin sulfate proteoglycans. J Neurosci 19: 8979-8989.

Onofre GR, Werneck CC, Mendes FA, Garcia-Abreu J, Moura Neto V, Cavalcante LA and Silva LCF. 2001. Astroglial cells derived from lateral and medial midbrain sectors differ in their synthesis and secretion of sulfated glycosaminoglycans. Braz J Med Biol Res 34: 251-258.

Oohira A, Matsui F, Tokita Y, Yamauchi S and Aono S. 2000. Molecular interactions of neural chondroitin sulfate proteoglycans in the brain development. Arch Biochem Biophys 374: 24-34.

Orioli D AND KLEIN R. 1997. The Eph receptor family: axonal guidance by contact repulsion. Trends Genet 13: 354-359.

Orioli D, Henkemeyer M, Lemke G, Klein R And PAwson T. 1996. Sek4 and Nuk receptors cooperate in guidance of commissural axons and in palate formation. EMBO J 15: 6035-6049.

Orlino EN JR, Wong CM And Phelps PE. 2000. L1 and GAD65 are expressed on dorsal commissural axons in embryonic rat spinal cord. Dev Brain Res 125: 117-130.

Park S, Frisen J And Barbacid M. 1997. Aberrant axonal projections in mice lacking EphA8 (Eek) tyrosine protein kinase receptors. EMBO J 16: 31063114.

Parpura V, Haydon PG and Henderson E. 1993. Three-dimensional imaging of living neurons and glia with the atomic force microscopy. J Cell Sci 104: 427-432.

Piepkorn M, Hovingh P, Bennett KL and Linker A. 1999. Heparan sulfate composition of alternatively spliced CD44 fusion proteins. Biochem Biophys Res Commun 257: 839-842.
Pires-Neto MA, Braga-De-Souza S and Lent R. 1998. Molecular tunnels and boundaries for growing axons in the anterior commissure of hamster embryos. J Comp Neurol 399: 176-188.

Plump AS, Erskine E, Sabatier C, Brose K, Epstein CJ, Goodman CS, Mason CA and TessierLAVIGNE M. 2002. Slit1 and slit2 cooperate to prevent premature midline crossing of retinal axons in the mouse visual system. Neuron 33: 219-232.

Postuma RB, He W, Nunan J, Beyreuther K, MasTers CL, Barrow CJ and Small DH. 2000. $\beta$ amyloid peptides inhibit cell adhesion and neurite outgrowth in primary neuronal cultures. J Neurochem 74: 1122-1130.

Puelles L. 1995. A segmental morphological paradigm for understanding vertebrate forebrains. Brain Behav Evol 46: 319-337.

Radmacher M, Tillman RW, Fritz M and Gaub HE. 1992. From molecules to cells: imaging of soft samples with the atomic force microscope. Science 257: 1900-1905.

Raedler E, Raedler A and Feldhaus S. 1981. Prenatal differentiation of colliculus superior in the rat. Bibl Anat 19: 174-191.

RAPER JA. 2000. Semaphorins and their receptors in vertebrates and invertebrates. Curr Opin Neurobiol 10: 88-94.

Riopelle RJ And Dow KE. 1990. Functional interaction of neuronal heparan sulphate proteoglycans with laminin. Brain Res 525: 92-100.

Ronca F, Andersen JS, Paech V and Margolis RU. 2001. Characterization of Slit protein interactions with glypican-1. J Biol Chem 276: 29141-29147.

Sakurai T, Lustig M, Nativ M, Hemperly JJ, SchLessinger J, Peles E and Grumet M. 1997. Induction of neurite outgrowth through Contactin and $\mathrm{Nr}-\mathrm{CAM}$ by extracellular regions of glial Receptor Tyrosine Phosphatase $\beta$. J Cell Biol 136: 907-918.

SANDERSON RD AND LANDER A. 1999. Relationships between structure and function of syndecans and glypicans. In Lander A, Nakato H, Selleck SB, TurnBull JE AND COATH C (eds.) Cell surface proteoglycans in signaling and development, HFSP, Strasbourg, pp. 103-112. 
SAntiago MF, Berredo-Pinho M, Gandra M, Costa MR, Cavalcante LA and Mendez-Otero R. 2001. Expression and function of ganglioside 9-Oacetyl GD3 in post-mitotic granule cell development. Mol Cell Neurosci 17: 488-499.

Scully AL, McKeown M and Thomas JB. 1999. Isolation and characterization of Dek, a Drosophila Eph receptor protein tyrosine kinase. Mol Cell Neurosci 13: 337-347.

Shiga T, Oppenheim RW, Grumet M and Edelman GM. 1990. Neuron-glia cell adhesion molecule (NgCAM) expression in the chick embryo spinal cord: observations on the earliest developing intersegmental interneurons. Dev Brain Res 55: 209-217.

Smith VL. 1983. The development and postnatal organization of primary afferent projections to the rat thoracic spinal cord. J Comp Neurol 220: 29-43.

Snow AD, Sekiguchi R, Nochlin D, Fraser P, Kimata K, Mizutani A, Arai M, Schreier WA and MorGAN DG. 1994. An important role of heparan sulfate proteoglycan (Perlecan) in a model system for the deposition and persistence of fibrillar A beta-amyloid in rat brain. Neuron 12: 219-234.

Snow DM, Steindler DA AND Silver J. 1990a. Molecular and cellular characterization of the glial roof plate of the spinal cord and optic tectum: a possible role for a proteoglycan in the development of an axon barrier. Dev Biol 138: 359-376.

Snow DM, Lemmon V, Carrino DA, Caplan AI AND SiLVER J. 1990b. Sulfated proteoglycans in astroglial barriers inhibit neurite outgrowth in vitro. Exp Neurol 109: 111-130.

Snow DM, Brown EM and Letourneau PC. 1996. Growth cone behavior in the presence of soluble chondroitin sulfate proteoglycan (CSPG), compared to behavior on CSPG bound to laminin or fibronectin. Int J Dev Neurosci 14: 331-349.

Sommer L, Rao M And Anderson DJ. 1997. RPTP $\delta$ and the novel protein tyrosine phosphatase RPTP $\psi$ are expressed in restricted regions of the developing central nervous system. Dev Dyn 208: 48-61.

Sretavan DW, Feng L, Pure E and Reichardt LF. 1994. Embryonic neurons of the developing optic chiasm express L1 and CD44, cell surface molecules with opposing effects on retinal axon growth. Neuron 12: $957-975$.
STOKer AW. 2001. Receptor tyrosine phosphatases in axon growth and guidance. Curr Opin Neurobiol 11: 95-102.

Suga H, Koyanagi M, Hoshiyama D, Ono K, Iwabe N, Kuma K and Miyata T. 1999. Extensive gene duplication in the early evolution of animals before the parazoan-eumetazoan split demonstrated by G proteins and protein tyrosine kinases from sponge and hydra. J Mol Evol 48: 646-653.

Sun Q, Bahri S, Schmid A, Chia W and Zinn K. 2000. Receptor tyrosine phosphatases regulate axon guidance across the midline of the Drosophila embryo. Development 127: 801-812.

Talts JF, Andac Z, Göhring W, Brancaccio A and TIMPL R. 1999. Binding of the $\mathrm{G}$ domains of laminin $\alpha 1$ and $\alpha 2$ chains and perlecan to heparin, sulfatides, $\alpha$-dystroglycan and several extracellular matrix proteins. EMBO J 18: 863-870.

Tamada A, Shirasaki R and Murakami F. 1995. Floor plate chemoattracts crossed axons and chemorepels uncrossed axons in the vertebrate brain. Neuron 14: 1083-1093.

TAMAgnone L and Comoglio PM. 2000. Signalling by semaphorin receptors: cell guidance and beyond. Trends Cell Biol 10: 377-383.

TARDY M. 2002. Role of laminin bioavailability in the astroglial permissivity for neuritic outgrowth. An Acad Bras Cienc 74: 683-690.

Tessier-Lavigne M and Goodman CS. 1996. The molecular biology of axon guidance. Science 274 : 1123-1133.

Timpl R, Rodde H, Robey PG, Rennard SI, Foidart JM AND MARTIN GR. 1979. Laminin: a glycoprotein from basement membrane. J Biol Chem 254: 9933 9937.

Tobey SL, McClelland KJ and Culp LA. 1985. Neurite extension by neuroblastoma cells on substratumbound fibronectin's cell-binding fragment but not on the heparan sulfate-binding protein, platelet factor-4. Exp Cell Res 158: 395-412.

Toikka J, Aalto J, Häyrinen J, Pelliniemi LJ And FINNE J. 1998. The polysialic acid units of the neural cell adhesion molecule N-CAM form filament bundle networks. J Biol Chem 273: 28557-28559. 
Tran TS And Phelps PE. 2000. Axons crossing in the ventral commissure express L1 and GAD65 in the developing rat spinal cord. Dev Neurosci 22: 228236.

Turnbull J, Powell A And Guimond S. 2001. Heparan sulfate: decoding a dynamic multifunctional cell regulator. Trends Cell Biol 11: 75-82.

Van Hartesveldt C, Moore B and Hartman BK. 1986. Transient midline raphe glial structure in the developing rat. J Comp Neurol 253:175-184.

Van Horssen J, Wilhelmus MM, Heljasvaara R, PihLaJANiemi T, Wesseling P, De WaAl RM and VerBEEK MM. 2002. Collagen XVIII: a novel heparan sulfate proteoglycan associated with vascular amyloid depositions and senile plaques in Alzheimer's disease brains. Brain Pathol 12: 456-462.

Varela-Echavarria A, Tucker A, Puschel AW and Guthrie S. 1997. Motor axon subpopulations respond differentially to the chemorepellents netrin-1 and semaphorin D. Neuron 18: 193-207.

Verbeek MM, Otte-Höller I, Van den Born J, Van Den Heuvel LPWJ, David G, Wesseling P ANd De WAAL RMW. 1999. Agrin is a major heparan sulfate proteoglycan accumulating in Alzheimer's disease brain. Am J Pathol 155: 2115-2125.

Verna JM, Fichard A and Saxod R. 1989. Influence of glycosaminoglycans on neurite morphology and outgrowth patterns in vitro. Int J Dev Neurosci 7: 389-399.

Walz A, McFarlane S, Brickman YG, Nurcombe V, Bartlett PF ANd Holt CE. 1997. Essential role of heparan sulfates in axon navigation and targeting in the developing visual system. Development 124 : 2421-2430.

Wang LC, Dani J, Godement P, Marcus RC and Mason CA. 1995. Crossed and uncrossed retinal axons respond differently to cells of the optic chiasm midline in vitro. Neuron 15: 1349-1364.

Weissmüller G, Garcia-Abreu J, Bisch PM, Moura Neto V and Cavalcante LA. 2000. Glial cells with differential neurite growth-modulating properties probed by atomic force microscopy. Neurosci Res 38: 217-220.

Weyn B, Kalle W, Kumar-Singh S, Van Marck E, TANKe H AND JACOB W. 1998. Atomic force mi- croscopy: influence of air drying and fixation on the morphology and viscoelasticity of cultured cells. J Microsc 189(Pt 2): 172-180.

Winkler S, Stahl RC, Carey DJ AND Bansal R. 2002. Syndecan-3 and perlecan are differentially expressed by progenitors and mature oligodendrocytes and accumulate in the extracellular matrix. J Neurosci Res 69: 477-487.

Wu D-Y, Jhaveri S ANd Schneider GE. 1995. Glial environment in the developing superior colliculus of hamsters in relation to the timing of retinal axon ingrowth. J Comp Neurol 358: 206-218.

YAMAGUCHI Y. 2001. Heparan sulfate proteoglycans in the nervous system: their diverse roles in neurogenesis, axon guidance, and synaptogenesis. Semin Cell Dev Biol 12: 99-106.

Yamane Y, Tohno-oka R, Yamada S, Furuya S, Shiokawa K, Hirabayashi Y, Sugino H and SugaHARA K. 1998. Molecular characterization of Xenopus embryo heparan sulfate. Differential structural requirements for the specific binding to basic fibroblast growth factor and follistatin. J Biol Chem 273: 7375-7381.

Yulis CR, Mota MD, Andrades JA, Rodriguez S, Peruzzo B, Mancera JM, Ramirez P, Garrido M, Perez-Figarez JM, Fernandez-Llebrez P AND Rodriguez EM. 1998. Floor plate and the subcommissural organ are the source of secretory compounds of related nature: comparative immunocytochemical study. J Comp Neurol 392: 19-34.

Yurchenco PD, Tsilibary EC, Charonis AS AND FURTHMAYR H. 1985. Laminin polymerization in vitro. Evidence for a two-step assembly with domain specificity. J Biol Chem 260: 7636-7644.

Yurchenco PD, Cheng YS and Ruben GC. 1987. Selfassembly of a high molecular weight basement membrane heparan sulfate proteoglycan into dimers and oligomers. J Biol Chem 262: 17668-17676.

Yurchenco PD, Cheng Y-S And Schittny JC. 1990. Heparin modulation of laminin polymerization. J Biol Chem 265: 3981-3991.

ZHou FC. 1990. Four patterns of laminin-immunoreactive structure in developing rat brain. Brain Res Dev Brain Res 55: 191-201.

Zhou XH, Brakebusch C, Matthies H, Oohashi T, 
Hirsch E, Moser M, Krug M, Seidenbecher CI, Boeckers TM, Rauch U, Buettner R, GundelFINGER ED AND FASSLER R. 2001. Neurocan is dispensable for brain development. Mol Cell Biol 21: 5970-5978.
Zou Y, Stoeckli E, Chen H and Tessier-Lavigne M. 2000. Squeezing axons out of the gray matter: a role for slit and semaphorin proteins from midline and ventral spinal cord. Cell 102: 363-375. 